\title{
A framework to quantify the human footprint in Africa using supply and demand of net primary production $^{1}$
}

\author{
Abdulhakim M. Abdi \\ Centre for Environmental and Climate Research, Lund University, SE-223 62 Lund, Sweden \\ Department of Physical Geography and Ecosystem Science, Lund University, SE-223 62 Lund, Sweden \\ Email: hakim.abdi@cec.lu.se
}

\begin{abstract}
The human-environment connection in the mostly rural drylands of Africa forms a complex, interlinked system that provides ecosystem services. This system is susceptible to climatic variability that impacts the supply of its products, and high population growth, which impacts the demand for these products. When plants remove carbon dioxide from the atmosphere through the process of photosynthesis, they use some of this carbon to maintain plant cellular structure. The rest is stored as plant tissue and forms plant biomass. The annual accumulation of this plant biomass is called net primary production (NPP). On an annual basis, NPP supplies the provision of crops, animal feed and pasture. The societal implications of reduced NPP can be severe, possibly leading to crop failure and eventual food insecurity.

This paper focuses on a method of quantifying the human impact on ecosystems using satellite-derived estimates of NPP and quantitative data on the demand for food, feed, and fuel. This work leans on three main sources (see footnote) and streamlines key concepts introduced therein. The first section is an introduction to the link between humans and the environment in the drylands of Africa. The second section describes the role of climate and the concept of primary production, and the history of its estimation using data from Earthobserving satellites. The third section presents the various consumable components necessary for human survival and their statistical derivation. The fourth section details the conceptual framework that is based on the supply and demand of NPP. The fifth section broadly discusses the framework's advantages and limitations, other studies that attempt to quantify human impact on ecosystems as well as knowledge gaps and future research needs.
\end{abstract}

Keywords: Africa, Arid, CSDI, Carbon Supply and Demand Index, CHANS, Coupled Human and Natural Systems, Drylands, Earth Observation, Food, Feed, Fuel, HANPP, Human Appropriation of NPP, Net Primary Production, Net Primary Productivity, NPP, Sahel, Semi-arid, Vegetation.

\footnotetext{
${ }^{1}$ This paper harmonizes concepts and content from the author's PhD dissertation [1] and three key peer-reviewed publications [2-4].
} 


\section{Table of Contents}

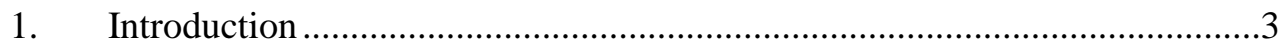

1.1. The human-environment connection in African drylands .................3

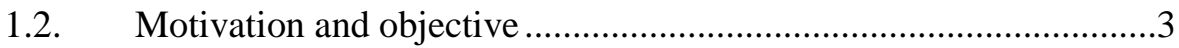

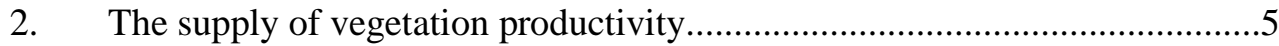

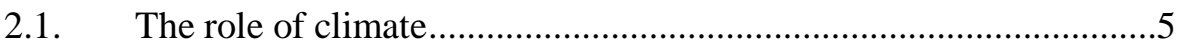

2.2. Gross and net primary production .................................................

2.2.1. Observing primary production from space ...............................6

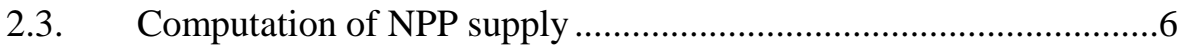

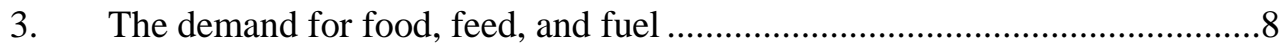

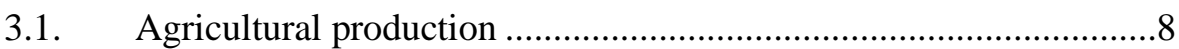

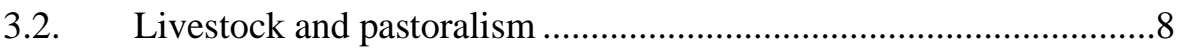

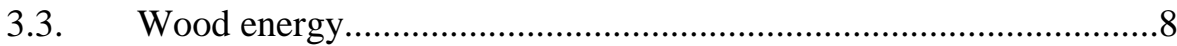

3.4. Computation of NPP demand .........................................................10

4. The balance between supply and demand of NPP ......................................12

4.1.1. Demand-supply ratio of NPP (DSR) ...................................12

4.1.2. The carbon supply and demand index (CSDI) ......................12

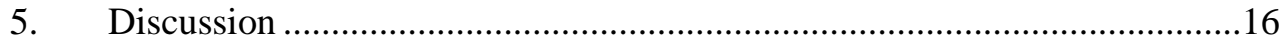

5.1. Past and present perspectives.........................................................16

5.2. Methodological caveats and practicalities .....................................17

5.3. Advancement of satellite-derived G/NPP.......................................18

5.3.1. Importance of capacity building in improving G/NPP ...........19

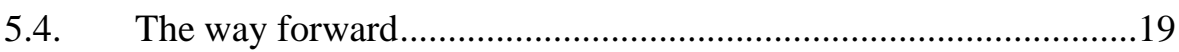

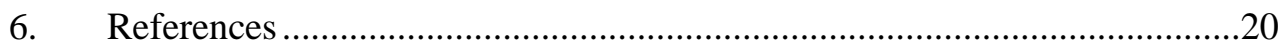

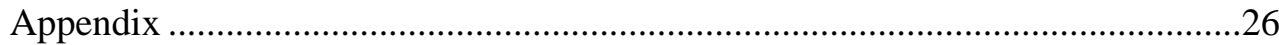




\section{Introduction}

\subsection{The human-environment connection in African drylands}

More than half of the African continent can be classified as a dryland system that is characterized by low rainfall and high evapotranspiration (Figure 1). Indeed, Africa contains some of the driest regions on Earth that constitute some of the oldest continually inhabited environments [5]. Our understanding of these systems has changed over time. The Scottish philosopher Adam Smith posited in his 1776 work, "The Wealth of Nations", that the natural progression of livelihoods was from hunter to pastoralist to farmer [6]. However, it is now well-known that pastoralism evolved from agriculture as an alternative means of subsistence in arid and semi-arid regions during periods of drought [7].

A considerable portion of the population of Africa lives in rural drylands that form complex landscapes (Figure 2) where agriculture, pastoralism and agro-pastoralism are the principal livelihoods [8]. Most of Africa has one rainy season, except East Africa, which has two. Each rainy season lasts between one to three months and is the principal growing season for vegetation, both natural and farmed. The end of the rainy season heralds the start of the dry season when drought conditions take hold and both human and natural systems adopt measures that ensure their survival. In the natural system, herbaceous vegetation senesces, seeds remain dormant, and drought-deciduous trees shed leaves to minimize water loss [8]. Some trees with deep roots and succulent shrubs with water storing mechanisms remain green during the dry season, and serve as forage for livestock and wild game.

The people of African drylands have developed effective adaptation and mitigation strategies, rooted in local knowledge, to cope with the high climatic variability. The dry season is the time for pastoralists and agropastoralists to move their livestock herds to where there are pastures. Farmers, on the other hand, exploit market opportunities during the dry season by engaging in activities such as seasonal economic migration, trade in arts and crafts, and artisanal mining [9-11]. For example, during the dry season in central Sudan it is common for the majority of young men from farming villages to undertake economic migration to the capital Khartoum or to the gold mines in the north of the country ${ }^{2}$.

Droughts are common in Africa, and in the event of one the dry season can be prolonged causing extended drought conditions. Between 1900 and 2013, 642 droughts were reported across the world [12]. Forty-five percent (291) of these droughts were in Africa and affected 362 million people, including 847,143 mortalities [12]. However, it is important to note that mortalities coincident with periods of intense drought are not only a function of drought itself, but also the dominant political ecosystem [13]. For example, the devastating drought of 1972-75 severely impacted the Horn of Africa and caused a minimum of 200,000 deaths ${ }^{3}$ in Ethiopia $[15,16]$. In contrast, during the same drought neighboring Somalia experienced a distinctly lower casualty level ( 20,000 deaths) due to a relatively proactive intervention by the government $[17,18]$. On the other hand, the rainy season can be intense, i.e. large amounts of rain falling over a relatively short period of time, and can cause widespread flooding as happened in 2007 when 45 heavy rainfall events displaced 2.5 million people across several countries in Africa [19].

\subsection{Motivation and objective}

The human-environment connection in the drylands of Africa forms a complex, interlinked system that provides ecosystem services. The majority of food consumed in the region comes from domestic sources [20], making the natural system a crucial direct factor that acts both as a source of livelihood and nutrition. However,

\footnotetext{
2 According to group interviews conducted by the author in the village of Naseem $\left(13.351^{\circ} \mathrm{N}, 30.499^{\circ} \mathrm{E}\right)$, North Kordofan, Sudan on January, $25^{\text {th }} 2014$.

3 This estimate has been challenged by several authors, see for example: [10] Caldwell, J.C., Demographic aspects of drought: An examination of the African drought of 1970-74. African Environment Special Report, 1977. 6: p. 93-100.
} 
this system is susceptible to climatic variability that affects the supply of its products, and high population growth and socioeconomics, which affect demand for these products. The objective of this paper is to harmonize and expand upon a relatively straightforward and easily calculable metric that quantifies the human footprint from the perspective of provision and extraction of plant-based products. This paper represents a first step in the development of such a metric. The simple framework proposed here combines two sets of quantitative data on: (1) land productivity derived from Earth observation satellites, and (2) consumption of plant-based products derived from statistical databases. The key objective behind the framework is to capture human impact on ecosystems through the demand for products of photosynthesis in relation to their supply in the ecosystem.

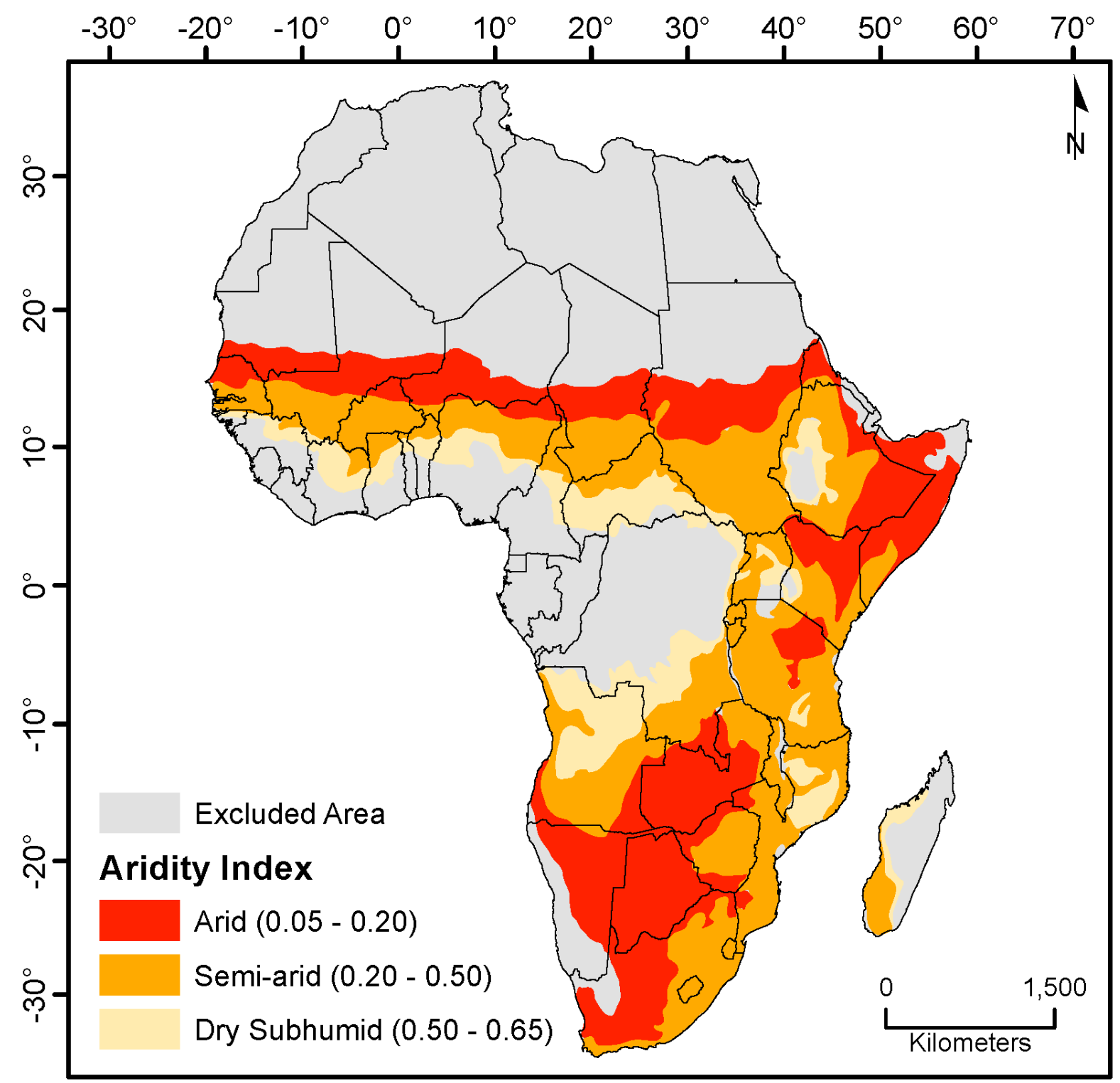

Figure 1: Dryland ecosystems included in this paper. The aridity index (AI) values in the parentheses were computed as the ratio of precipitation to potential evapotranspiration as per Budyko [21]. Data on precipitation from Funk, Peterson [22] and potential evapotranspiration from Mu, Zhao [23] averaged for the period 2000 2014 were used to produce this figure. 


\section{The supply of vegetation productivity}

\subsection{The role of climate}

In the drylands of Africa both temperature and water availability control critical biogeochemical processes that are important for vegetation growth. Water is particularly important as a limiting factor for vegetation growth in drylands systems [24-31]. Merbold, Ardö [32] found that mean annual rainfall is strongly correlated with maximum photosynthetic capacity and is the predominant factor driving the exchange of carbon dioxide $\left(\mathrm{CO}_{2}\right)$ between the land and the atmosphere over African ecosystems. Rainfall replenishes plant available water and reduces land surface temperature through latent heat loss from surface soil moisture [33]. Rainfall also causes higher humidity levels and allows leaf stomata to stay open for longer periods [8]. When plants transpire, the mixture of air and water exiting the stomata is saturated at a relative humidity of $\sim 100 \%$ [34]. The difference between amount of water in the air and the maximum amount of water the air can hold when it is saturated at higher temperature is called the vapor pressure deficit [35]. This deficit, along with plant available water, limits photosynthesis (and thereby plant growth) by causing extended closure of the stomata and prohibiting the flow of $\mathrm{CO}_{2}$ into the leaf [4].

\subsection{Gross and net primary production}

Gross primary production (GPP) is the total amount of $\mathrm{CO}_{2}$ plants extract from the atmosphere through the process of photosynthesis. Some of this carbon goes to maintain plant cellular structure and is thus lost through autotrophic respiration $(\mathrm{Ra})$. The remaining carbon is stored as plant tissue, forming plant biomass (phytomass). The annual accumulation of phytomass is referred to as net primary production (NPP $=$ GPP Ra). On an annual basis, NPP supplies the provision of crops, animal feed and pasture. The societal implications of reduced NPP can be severe, possibly leading to crop failure and eventual food insecurity [36]. The terms "primary production" and "primary productivity" are treated as synonymous in this paper 4

Field estimation of terrestrial GPP can be done using infrared gas chambers (e.g. Johnson and Kelley [37]) or leaf ${ }^{14} \mathrm{CO}_{2}$ assimilation studies (e.g. Szarek and Woodhouse [38]). These studies are not only time consuming, but require repetitive field visits and are based on small samples of the landscape. A particular difficulty in the measurement of GPP is that growth and maintenance respiration is a continuous process that consumes some of the assimilated carbon. Micrometeorological techniques such as the eddy covariance (EC) method [39] facilitated continuous measurements of $\mathrm{CO}_{2}$ (and other) fluxes across larger areas. The EC method uses towermounted instruments to measure net ecosystem exchange (NEE), i.e. the exchange of $\mathrm{CO}_{2}$ between terrestrial ecosystems and the atmosphere. This is done using the covariance between the oscillations in the vertical wind velocity and the $\mathrm{CO}_{2}$ mixing ratio in the air above a vegetation canopy [39].

Measuring NPP in the field involves harvesting the vegetation and calculating the annual growth of wood and the mass of foliage at the peak of annual leaf display [40]. It also involves measuring the difference in the mass of tissue harvested at the beginning and end of the growing season (Schlesinger, 1997). Since vegetation productivity varies spatially due to environmental conditions and, because fieldwork is both labor and cost intensive, it is expensive to conduct productivity measurements over large spatial extents. Thus, there is a need to estimate NPP at large scales in a relatively efficient way. One of the earliest applied methods was the use of empirical relationships. The first global estimates of primary production using this method was made by Lieth [41], who related NPP with temperature and precipitation as limiting factors. This work was subsequently the foundation for the first computer-generated map of NPP [42]. Some of the latest methods of estimating observed primary production across large scales use Earth observation (EO) platforms.

\footnotetext{
4 "Production" refers to the combination of inputs to create, or produce, an output during a given period of time, while "productivity" refers to the accretion of output in the production process.
} 


\subsubsection{Observing primary production from space}

Rouse, Haas [43] introduced the normalized difference vegetation index (NDVI) using data from the newly launched ERTS-1 (later renamed Landsat-1) Multispectral Scanner System (MSS) satellite. The index is the difference between the near-infrared $(700-1100 \mathrm{~nm})$ and red surface $(600-700 \mathrm{~nm})$ reflectance divided by their sum, and is a measure of detecting live green vegetation using satellites. This early research was important on two levels: (1) it identified a configurable and broadly applicable satellite-driven concept that directly relates to biophysical properties of vegetation, and (2) it laid down the foundation for future research in NPP using EO data. Around the same time as the first applications of EO data, parallel research was being conducted on estimating terrestrial primary production using the intrinsic properties of photosynthesis, i.e. the role of radiation [44-47]. Subsequently, Tucker, Holben [48] proposed the direct use of satellite data in order to "allow large-area assessment of net primary production or total dry matter accumulation." The advantages of using EO include, but are not limited to, (1) large-scale coverage, (2) frequent revisit times, (3) variable spatial resolutions, and (4) multispectral sensors that capture different segments of the electromagnetic spectrum.

The groundwork for production efficiency modeling using EO data was laid by Running [49] who refined the methodology to estimate NPP based on the light-use-efficiency (LUE) concept of Monteith [50] and Monteith [46]. The basis of this concept is that GPP is the product of absorbed photosynthetically active radiation (APAR) (i.e. between 400 and $700 \mathrm{~nm}$ ) and a factor that represents the efficiency (LUE) with which a plant converts this radiation into phytomass. The availability of EO data and flux measurements from EC towers paved the way for innovative methods that combine these two data sources. Running, Justice [51] outlined the derivation of vegetation products from the Moderate Resolution Imaging Spectroradiometer (MODIS) sensor onboard the Terra and Aqua satellites launched by the United States National Aeronautics and Space Administration (NASA). These products were included a biogeochemical model to produce GPP and NPP on a near-continuous basis, and validated at several EC flux tower sites representing different biomes [52-54]. The MOD17 production efficiency model [55] emerged out of these developments and provides near-real-time estimates of terrestrial carbon uptake. MOD17 uses MODIS spectral data and climatic drivers in an LUE model [56].

Several studies have evaluated the models produced by MOD17. The algorithm has been found to underestimate GPP (and by extension NPP) in African ecosystems, primarily due to an underestimation of the biome-specific optimum LUE parameter and inadequate accounting of water stress conditions [30, 31, 57]. Recent studies have attempted to improve MODIS GPP estimates in African drylands. For example, Tagesson, Ardö [58] was able to upscale improved GPP estimates at five sites using photosynthetic capacity and quantum efficiency parametrized with MODIS-derived vegetation indices, and Abdi, Boke-Olén [4] found that a new MODIS-based index called the Plant Phenology Index (PPI) improves GPP estimates in four sites.

\subsection{Computation of NPP supply}

The MOD17 NPP product is currently the only satellite-driven estimate of NPP available for global applications and forms the basis of the supply of NPP detailed in this paper. The MOD17 algorithm uses the aforementioned LUE approach using a combination of spectral data from MODIS sensor and climatic data:

$$
N P P_{\text {Supply }}=\left(P A R^{*} F P A R^{*} \varepsilon_{\max } * V P D^{*} T_{\min }\right)-R a
$$

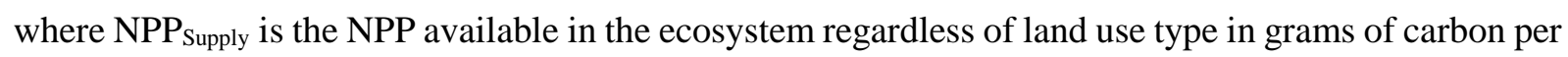
meter square per year $\left(\mathrm{g} \mathrm{C} \mathrm{m}^{-2} \mathrm{yr}^{-1}\right)$; PAR is incoming photosynthetically active radiation in megajoules per meter square per year $\left(\mathrm{MJ} \mathrm{m}^{-2} \mathrm{yr}^{-1}\right)$; FPAR is the fraction of incident PAR absorbed by the vegetation canopy; $\varepsilon_{\max }$ represents maximum light use efficiency, in grams of carbon per megajoule of PAR $\left(\mathrm{g} \mathrm{C} \mathrm{MJ}^{-1}\right)$, under hypothetical biome-specific ideal conditions; VPD and $\mathrm{T}_{\min }$ are simple linear ramp functions of vapor pressure deficit and minimum temperature, respectively, which constrain maximum light use efficiency; Ra (autotrophic respiration) represents the amount of carbon respired, in $\mathrm{g} \mathrm{C} \mathrm{m}^{-2} \mathrm{yr}^{-1}$, during maintenance and 
growth respiration of leaves, fine roots and woody tissue. Further descriptions of the MOD17 algorithm are detailed in [59] and Zhao, Running [60].

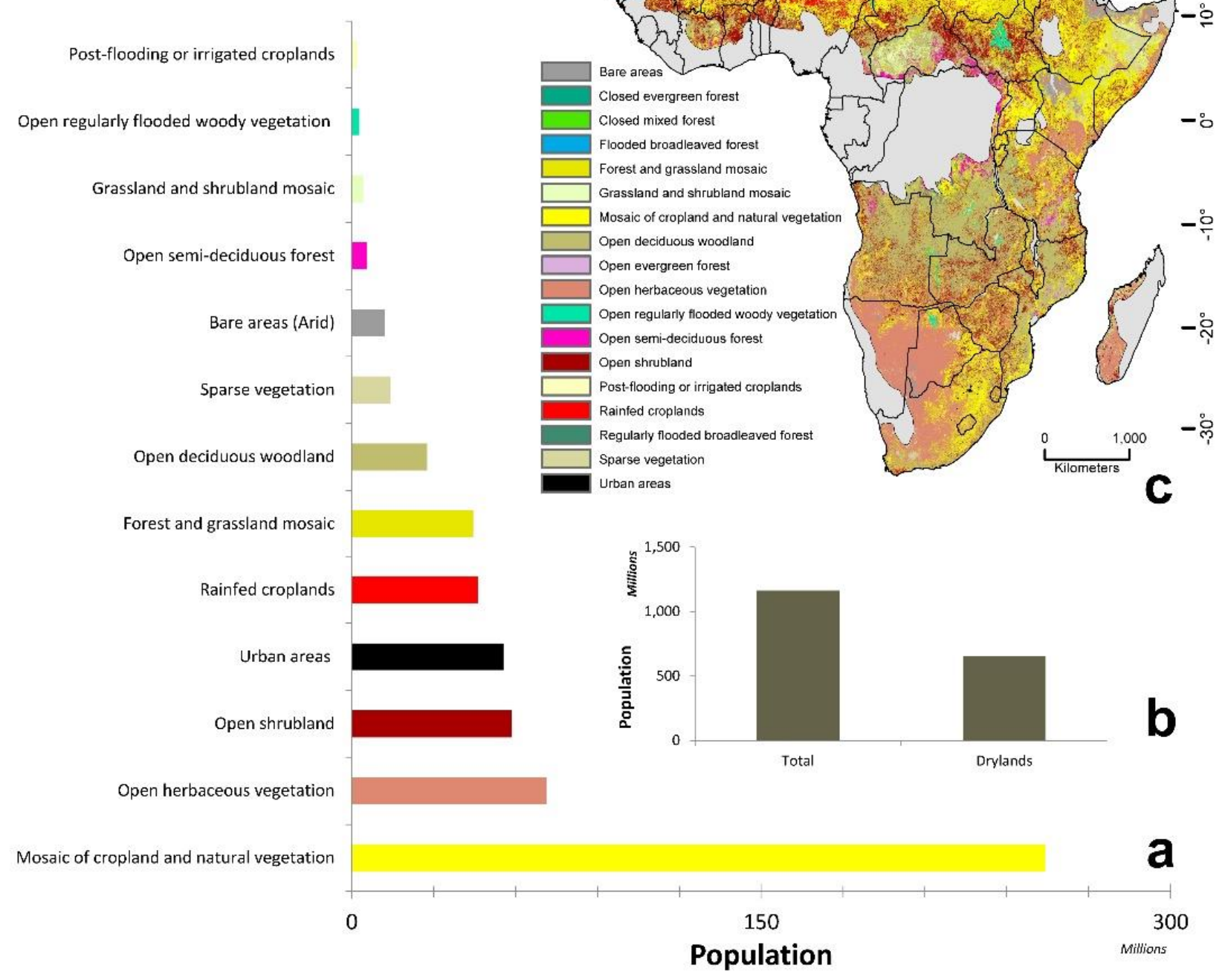

Figure 2: Population per land cover type in African drylands for the year 2010. An overview of (a) the population distribution per land cover type, (b) the population share of African drylands, (c) spatial distribution of the different land cover classes within the dryland extent. These values are based on gridded data on population from Linard, Gilbert [61] and land cover from Arino, Ramos Perez [62]. 


\section{The demand for food, feed, and fuel}

\subsection{Agricultural production}

African agriculture is predominantly rain-fed (Figure 3) indicating that rural livelihoods are almost completely dependent on prevailing climatic conditions. Domestic production of staple foods contributes approximately $90 \%$ of overall food consumption in Africa [20,63]. Consumption statistics vary by country, but the underlying pattern is that most of the national supplies of staple crops are used for either food or feed [64]. A recent study of the calorie delivery fraction of various agricultural products found that $80 \%$ of the crop calories produced in the region are used for food, $10 \%$ as feed, and $10 \%$ for other uses [65]. Although imported foods are becoming popular, mainly in upper class urban households [66], they do not contribute to the national economy as much as domestic foods do. For example, in West Africa, each US\$ 1 spent on local produce boosts the local economy by US\$ $1.96-2.88$ [67]. Additionally, most of the smallholder farms in Africa can be construed as closed systems with inadequate transportation networks and the consumption of much of what is locally produced [68]. Sustainable long-term food security depends on the development of the agricultural sector by providing access to markets to increase the resilience of domestic production.

\subsection{Livestock and pastoralism}

Livestock is an asset in Africa, and is dependent upon on for their nutritional value and generation of economic growth [3, 69]. Pastoralists and agro-pastoralists across African rangelands depend on grassland and savanna productivity as forage for livestock production (Figure 4). The contribution of the livestock sector to the national gross domestic product (GDP) varies considerably depending on the country. In countries where livestock is an important commodity (e.g. Sudan, Somalia) its contribution ranges between $30-40 \%$ of GDP $[70,71]$. The high climatic variability, demonstrated by the succession of dry and wet periods, is characteristic for most of the continent. Pastoralists develop adaptations in response to climatic variability and persistent drought, for example, switching to a livestock breed that can withstand drought [72] or has greater ability to digest browse [73].

\subsection{Wood energy}

In most parts of Africa household energy demand is met by woodfuels and is usually harvested in the form of dry or dead wood (Figure 5) [74]. First, a note on the terminology: (1) "fuelwood" refers to unprocessed woody biomass and is synonymous with "firewood", (2) "woodfuel" refers to an energy source that is derived from woody biomass, (3) "charcoal" is created by burning fuelwood in a low-oxygen environment, the resulting substance, consisting primarily of carbon, produces more energy per kilogram than the fuelwood from which it is derived. Woodfuels meet 55\% of the energy needs in Senegal [75], 72\% in Mali [76], 80\% in Sudan [77] and more than $90 \%$ in Chad [78]. However, these resources are under pressure due to rising demand. In East Africa, the proportion of woody biomass harvested in excess of the mean annual growth exceeds $50 \%$ in 43 sub-national units where a quarter of the population lives [79]. In the southern parts of the Sahel, the average tree canopy cover decreased from 14\% during the pre-drought 1960s to around $7 \%$ in the late 1980s, primarily due to the expansion of croplands [80]. 


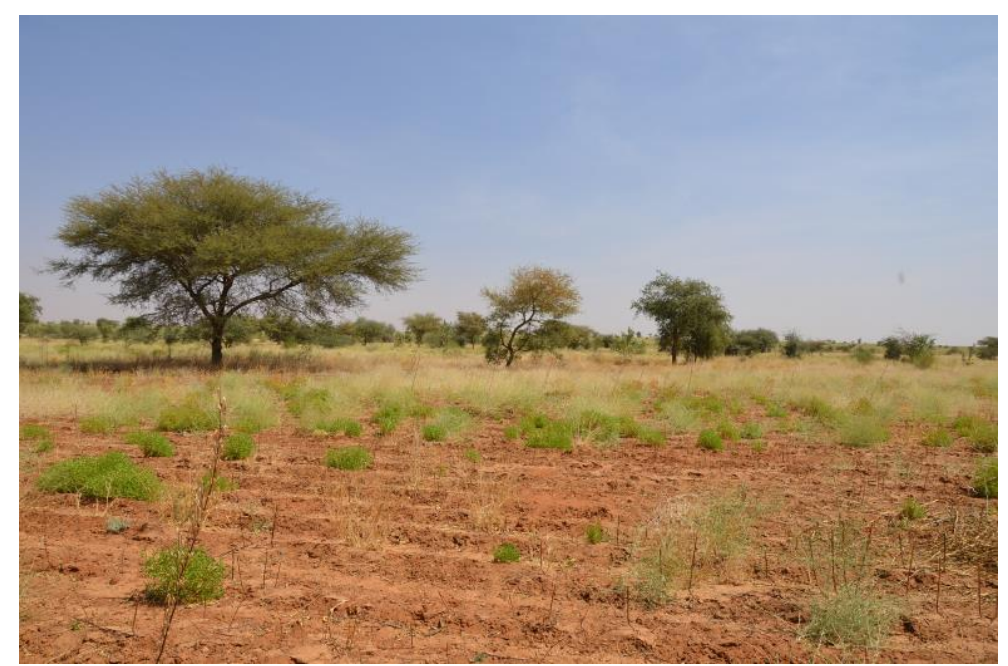

Figure 3: A fallow agricultural field in North Kordofan, Sudan, during the dry season (January 2014). Photo: Abdulhakim M. Abdi

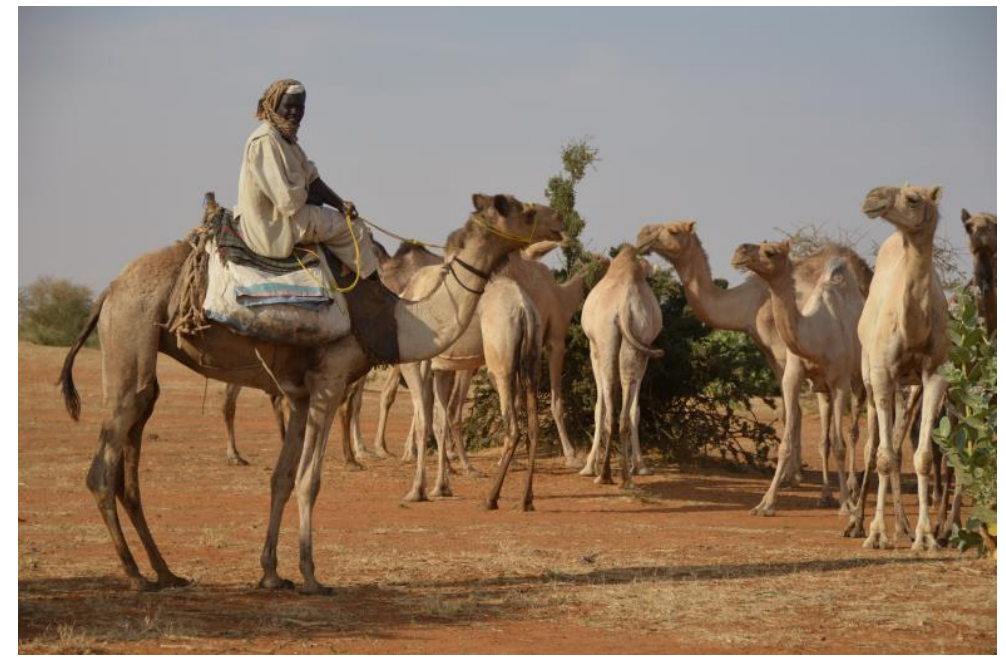

Figure 4: A pastoralist from the Shanabla tribe with his herd of camels in North Kordofan, Sudan during the dry season (January 2014). Photo: Abdulhakim M. Abdi. Permission was granted from the pastoralist for this photograph to be taken.

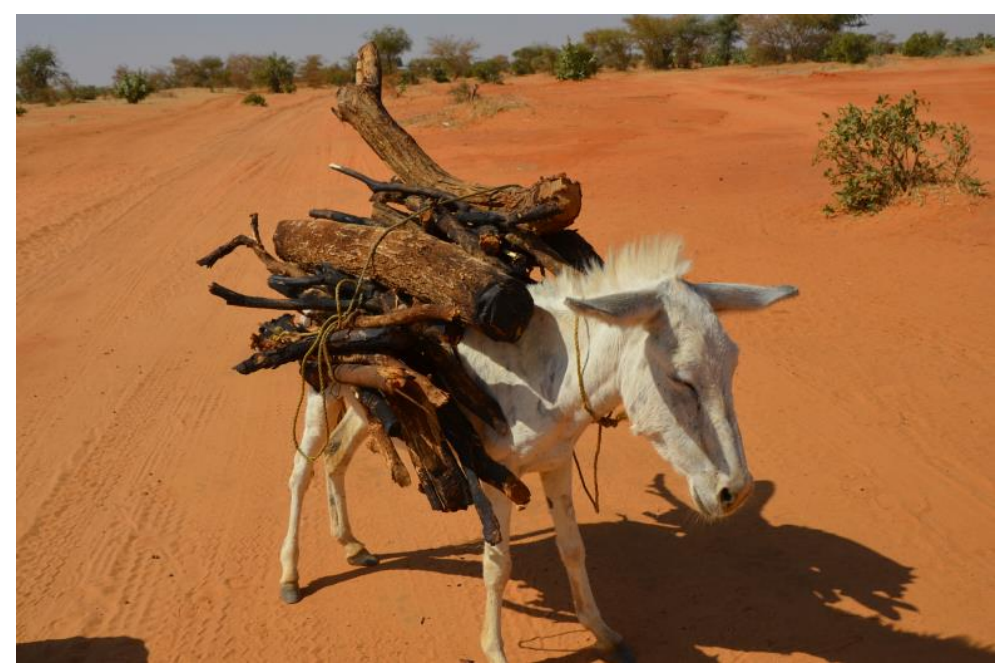

Figure 5: A donkey owned by a resident of the village of Luwaib in North Kordofan, Sudan laden with harvested wood (January 2014). Photo: Abdulhakim M. Abdi. 


\subsection{Computation of NPP demand}

In this paper, "consumption" and "demand" are considered different, but interrelated, concepts. "Consumption" is the actual amount of NPP extracted from the ecosystem as reported in the statistical database of the Food and Agriculture Organization of the United Nations (FAOSTAT, faostat3.fao.org/). "Demand" is the annual amount of NPP required to produce food, fuel and feed essential for the African dryland population as well as NPP lost during and after harvest. The computation of NPP demand is visualized in Appendix Figure 1. Abdi, Seaquist [2] used the total primary crop production for each country, which was later modified in Abdi, Vrieling [3] by using domestic supply quantities to account NPP supply for domestic utilization. Thus, the derivation of NPP demand presented in this section is based on the computations of Abdi, Vrieling [3].

The first component of NPP demand is domestically consumed food $\left(N P P_{\text {food }}\right)$. This category includes twentyseven types of regionally important primary crops, which represent $95 \%$ of all those that are domestically consumed by most of the countries in the study area [81] (Appendix Table 1). Additionally, meats sourced from six types of domestic animals (cattle, goats, sheep, pigs, camels, and poultry) and two non-meat animal products (eggs and milk) were also included.

$$
N P P_{\text {food }}=\overbrace{\left[\left(\sum_{p=1}^{27} P_{p, y}+I_{p, y}-E_{p, y}+S_{p, y}\right) \times D_{p, y} \times C_{p, y}\right]}^{\text {Crops }}+\overbrace{\left[\left(\sum_{a=1}^{7} M_{a, y}\right) \times K_{a, y} \times 0.45\right]}^{\text {Non-crop }}
$$

where, $P, I$ and $E$ are produced, imported and exported quantities of crop type $p$, in year $y ; S$ is the variation (positive or negative) in the stocks of crop type $p$, in year $y ; D$ and $C$ are the crop-specific dry matter and carbon conversion coefficients, respectively; $M$ is the wet carcass weight (i.e. without internal organs) of animal type $a$, in year $y$, and $K$ is the dry matter intake required to produce that weight, in year $y$. Crop tonnage was converted to carbon units using the conversion factors provided in Abdi, Seaquist [2]. The rationale behind converting crop tonnage to carbon units is due to the generally strong and statistically significant relationship between crop production and NPP in croplands (Appendix Figure 2).

Livestock are considered assets in Africa. Pastoralists and agro-pastoralists depend on livestock for nutritional value and economic growth. $N P P_{\text {feed }}$ represents the total amount of animal feed required to sustain the livestock population of the region.

$$
N P P_{\text {feed }}=\left(\sum_{a=1}^{6} T_{a, y}\right) \times R_{a, y} \times 0.45
$$

where, $T$ is the Tropical Livestock Unit (TLU) for livestock type $a$, in year $y ; R$ is the annual dry matter requirement as provided in Abdi, Seaquist [2]. A ratio of 0.45 was used to convert dry matter into carbon [2].

Crop residues $\left(N P P_{\text {residues }}\right)$ refer to the parts of the crop that are left over in a field after harvest. Thus, they are not part of the crop yield (i.e. edible seeds, roots, fruits, leaves, or stalks) and vary according to crop type.

$$
N P P_{\text {residues }}=\sum_{p=1}^{23} H_{p, y} \times 0.45
$$

where, $H$ is the residue factor (proportion of non-yield contributing crop phytomass) of crop type $p$, in year $y$. See the Appendix for the residue factors that were used.

In most parts of the Africa household energy demand is met by woodfuels comprising fuel wood and wood charcoal $\left(N P P_{\text {fuel }}\right)$ extracted from the region's dry woodlands. The demand for woodfuels across Africa is 
variable and ranges from 55\% in Senegal [75] to over 91\% in Malawi [82], but on average it is approximately $80 \%$ across the study area.

$$
N P P_{\text {fuel }}=\overbrace{\left(\sum W_{N C, y} \times 0.58 \times 0.45\right)}^{\text {Non-coniferous }}+\overbrace{\left(\sum W_{C N, y} \times 0.43 \times 0.45\right)}^{\text {Coniferous }}+\overbrace{\left(\sum W_{C H, y} \times 0.75\right)}^{\text {Charcoal }}
$$

where, $N C, C N$ and $C H$ represent non-coniferous, coniferous and wood charcoal. Dry matter conversion ratios of 0.58 and 0.43 were applied to the non-coniferous and coniferous fuel wood, respectively, and a ratio of 0.45 to convert dry matter into carbon. Wood charcoal was directly converted to carbon content by applying a ratio of 0.75 .

Landscape fires, both natural and anthropogenic, play an important role in African dryland ecosystems. One of the land use applications of burning in Africa is to expand cropland area [83]. Consequently, the amount of NPP lost to support human demand for food is taken into account. $N P P_{\text {burned }}$ represents domestic human-driven land conversion and NPP loss resulting from burning of both forest and savanna resources.

$$
N P P_{\text {burned }}=\sum B_{y} \times 0.45
$$

where, $B$ is the total amount of dry matter burnt in year $y$. The data are presented as dry matter content, therefore a ratio of 0.45 was used to convert dry matter into carbon.

A homogeneous per capita consumption within each country is not assumed due to variations in diet, lifestyle and wealth between urban and rural populations in Africa. Rather, ratio factors for urban and rural consumption were applied to national sums of each group of products based on statistics from peer-reviewed literature and national household consumption surveys.

$$
\begin{gathered}
N P P_{\text {demand_urban }}=\overbrace{N P P_{\text {food }}+N P P_{\text {feed }}+N P P_{\text {residues }}+N P P_{\text {fuel }}+N P P_{\text {burned }}}^{\text {Urban }} \\
N P P_{\text {demand_rural }}=\overbrace{N P P_{\text {food }}+N P P_{\text {feed }}+N P P_{\text {residues }}+N P P_{\text {fuel }}+N P P_{\text {burned }}}^{\text {Rural }} \\
N P P_{\text {Demand }}=N P P_{\text {demand_urban }}+N P P_{\text {demand_rural }}
\end{gathered}
$$

Per capita NPP consumption was computed by dividing rural and urban consumption values by each country's rural and urban population. Grids of urban and rural consumption were then merged to produce a single map of total per capita consumption. The data produced by Boke-Olén, Abdi [84] provides annual population estimates for Africa within 1-km grid cells for the $21^{\text {st }}$ century $(2000-2100)$. These estimates take into account both Representative Concentration Pathways (RCPs) urban fractions and Socio-Economic Pathways (SSPs) population projections stipulated in the fifth assessment of Intergovernmental Panel on Climate Change (IPCC). Urban and rural areas are separable from one another by masking the urban extent in population grids based on the "Urban Areas" category in the European Space Agency Climate Change Initiative (ESA CCI) land cover dataset (https://www.esa-landcover-cci.org/). This product provides a consistent global land cover classification at $300 \mathrm{~m}$ ground sampling distance from 1992 to 2018 using the FAO's standardized Land Cover Classification System. 


\section{The balance between supply and demand of NPP}

\subsubsection{Demand-supply ratio of NPP (DSR)}

NPP supplies the annual provision of crops, animal feed and pasture, and adds to annual increments of woody biomass. The societal implications of reduced NPP can be severe and could lead to crop failure and eventual food insecurity [36]. In this paper, the concepts of "supply" and "demand" are adopted to demonstrate the linkage between ecosystem productivity, human livelihood, and inter-annual climatic variability in African drylands. On the one hand, the population will continue to experiences increase in demand for NPP, as a function of population growth and per capita consumption [85]. On the other hand, forecasts of reduced productivity (up to $-41 \%$ ) of major crops due to increases in temperature have been consistent across different studies [86-89].

As demand for food, feed and fuel drives land use change, the proportion of NPP required by humans relative to climate-regulated supply (demand-supply ratio, DSR) (Figures 6 and 7) can serve as an integrated benchmark of human dependence on ecosystems. This is particularly essential for long-term trends in order to identify regions that are not vulnerable (e.g. Scenario 1 in Figure 6) and those that are vulnerable (e.g. Scenario 2 in Figure 6) to variations in NPP supply. A similar concept was used in North Kordofan, Sudan, by Olsson [90] who found that the proximity to a population center influences the availability of biomass. This suggests that there is a direct locally-constrained connection between the supply of NPP and demand for it (Figure 8 a). Olsson [90] also found that overutilization of land is only evident during periods of drought, which means that during periods of restricted resource availability demand surpasses supply in those areas. The future effects of extreme climatic variability, and eventual shifts in the climate system, could have strong impacts on this balance, and intensified by the need to keep pace with an increasing population [91].

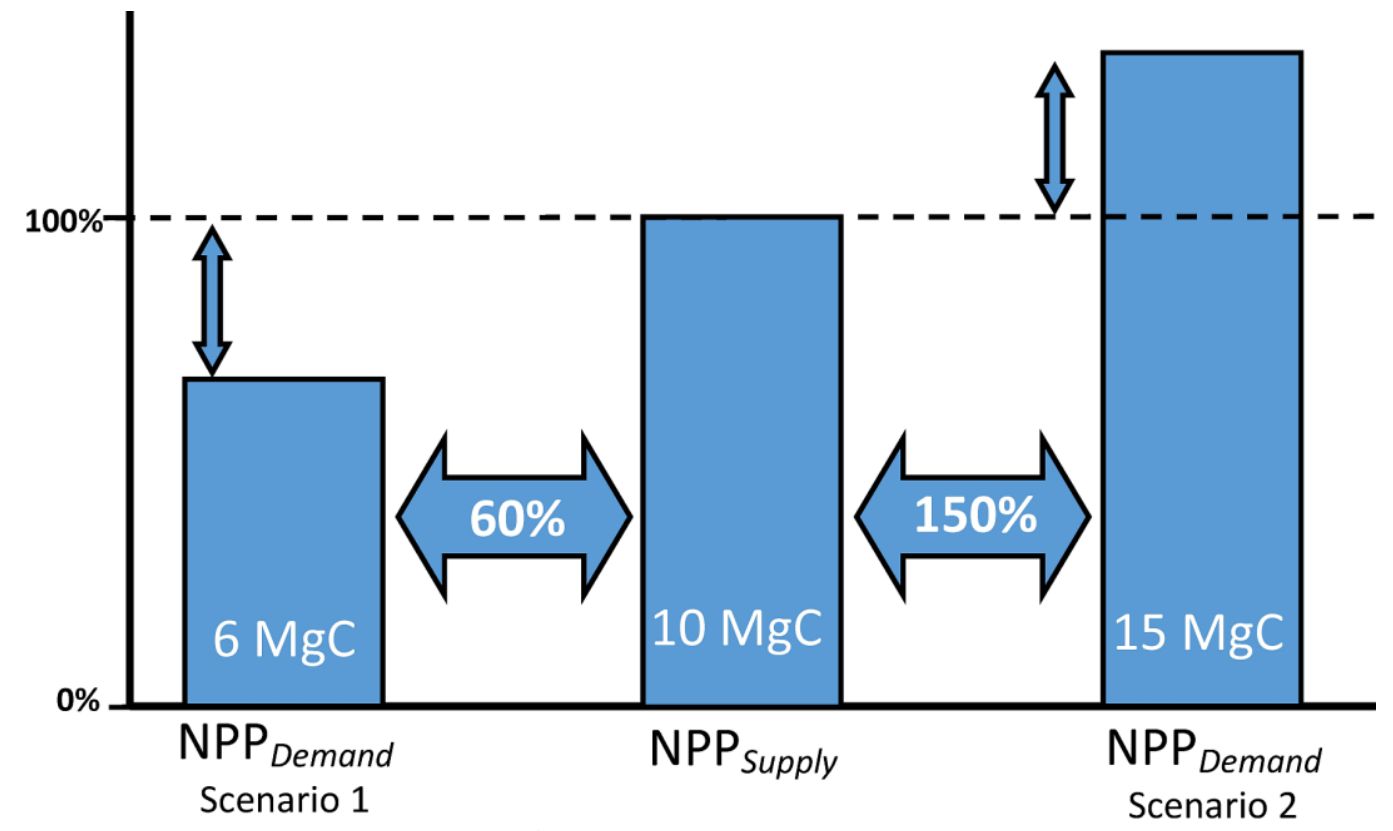

Figure 6: A conceptual overview of NPP supply and two scenarios of NPP demand. Scenario 1 shows a system where NPP demand is $60 \%$ of available supply. Scenario 2 shows a system where NPP demand has increased to is $150 \%$ of available supply, which means that NPP supply has to enter this system from elsewhere in order to satisfy demand.

\subsubsection{The carbon supply and demand index (CSDI)}

A dimensionless index, called the carbon supply and demand index (CSDI), based on equations 1 and 9 is used to quantify the impact of human demand for NPP on the landscape. 


$$
C S D I=\frac{N P P_{\text {Supply }}-N P P_{\text {Demand }}}{N P P_{\text {Supply }}+N P P_{\text {Demand }}}
$$

The index is restricted to values between +1 and -1 , where positive values correspond to increasing supply/decreasing demand, negative values to increasing demand/decreasing supply, and zero represents a balance between supply and demand. CSDI can patially map, in relative terms, the dynamics of NPP across space (Figure $8 \mathrm{~b}$ ), allowing the identification of areas where the balance between supply and demand of NPP is in flux. A key advantage of the CSDI is its ability to parsimoniously capture dynamics of NPP at a national level (Figure 9) and represent information contained in two different datasets. This enables the facilitation of the results in the straightforward manner using a single metric.
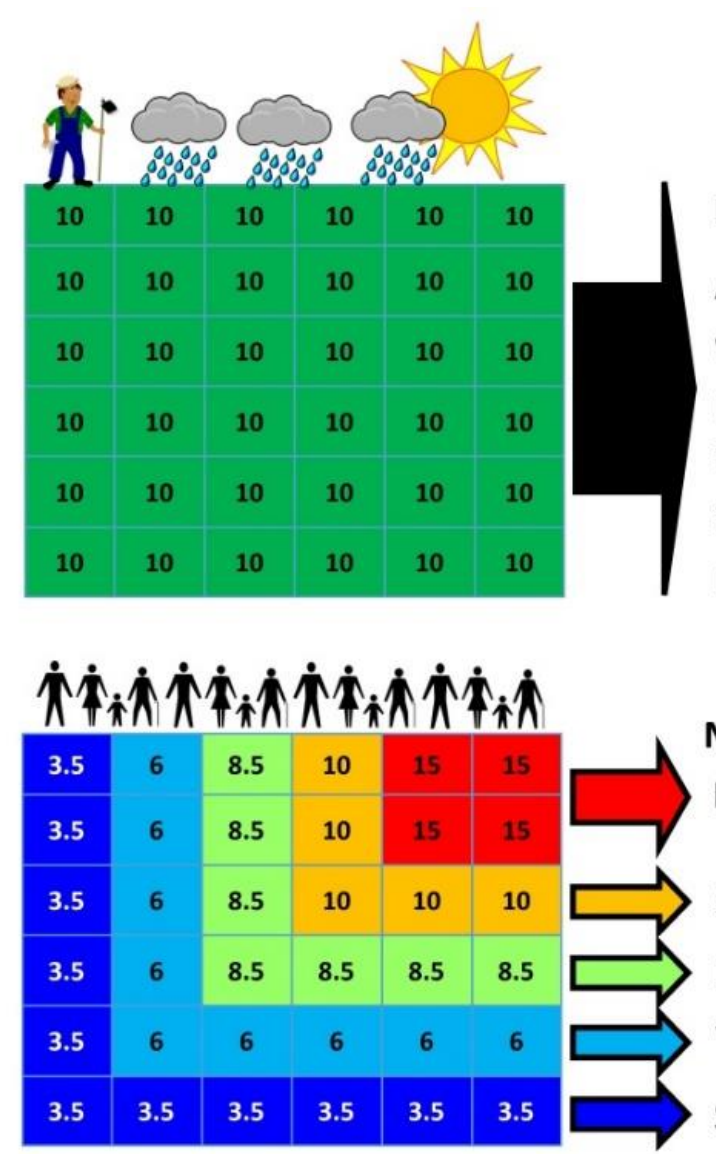

\section{NPP Supply}

A hypothetical vegetated landscape with an annual NPP production of 360 MgC. The NPP supply of each grid cell in this landscape is dictated by prevailing climatic condition and land use management.

\section{NPP Demand}

Densely populated urban landscape.

Suburban transitioning into dense rural.

Densely populated rural landscape.

Villages and agropastoral communities.

Sparsely populated pastoral landscape.
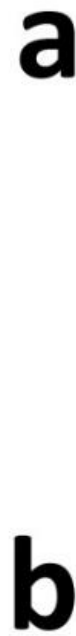
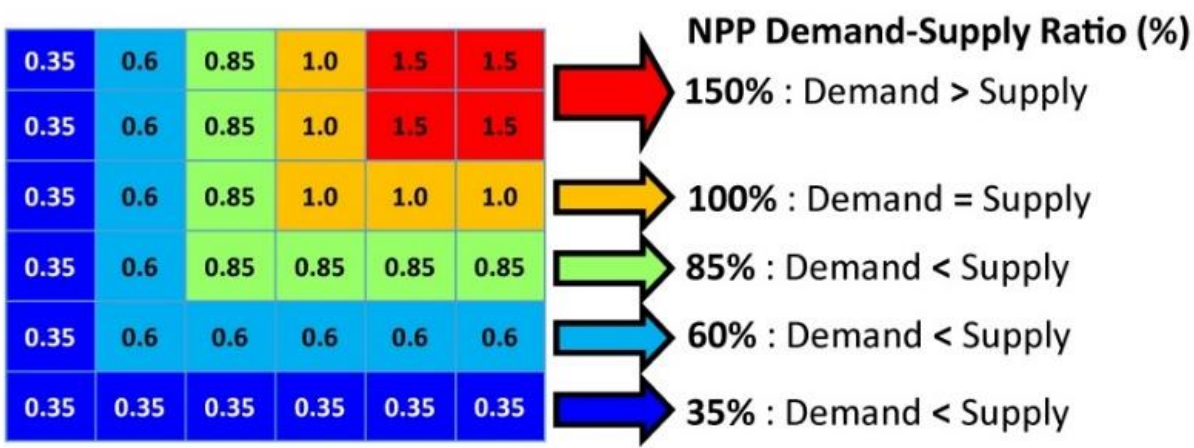

Figure 7: A spatial overview of the demand-supply balance of NPP. (a) The supply of NPP (MgC in this example) is governed either by climatic and land use conditions, while (b) the demand for NPP (MgC in this example) is a function of population density and dietary composition. (c) When these two concepts are spatialized and compared, it results in the demand-supply balance of NPP (demand-supply ratio, DSR). 


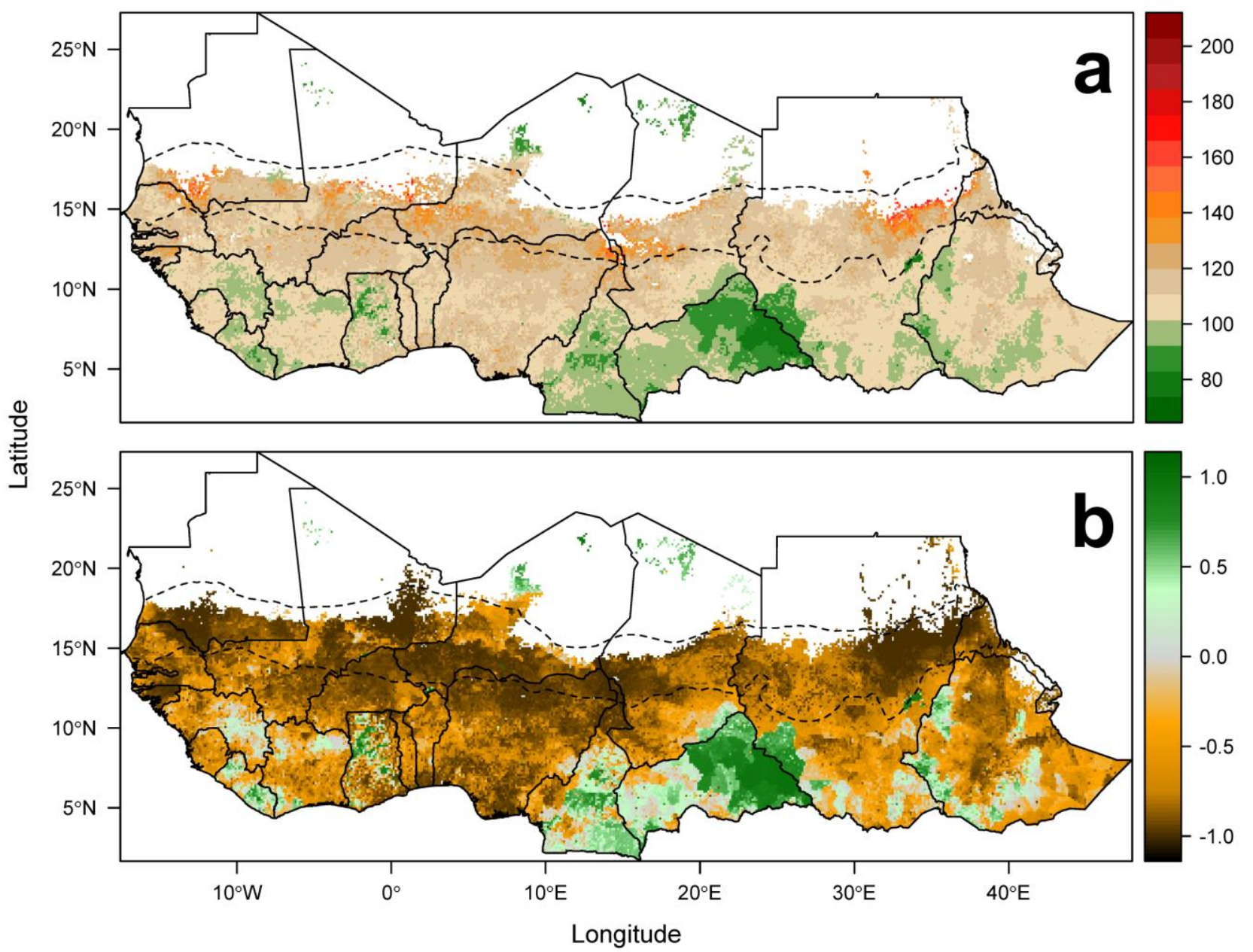

Figure 8: Spatial pattern of mean DSR and CSDI for 2000 - 2010. (a) Values for DSR represent the percent of available NPP that is consumed by the population with each grid cell. Since data on domestic production is used here, the flows of NPP remain within each country. (b) Positive CSDI values indicate higher levels of supply relative to demand while negative values indicate high demand relative to supply. Values around zero indicate areas where the supply and demand are in a balance. The dotted region represents the Sahel. 


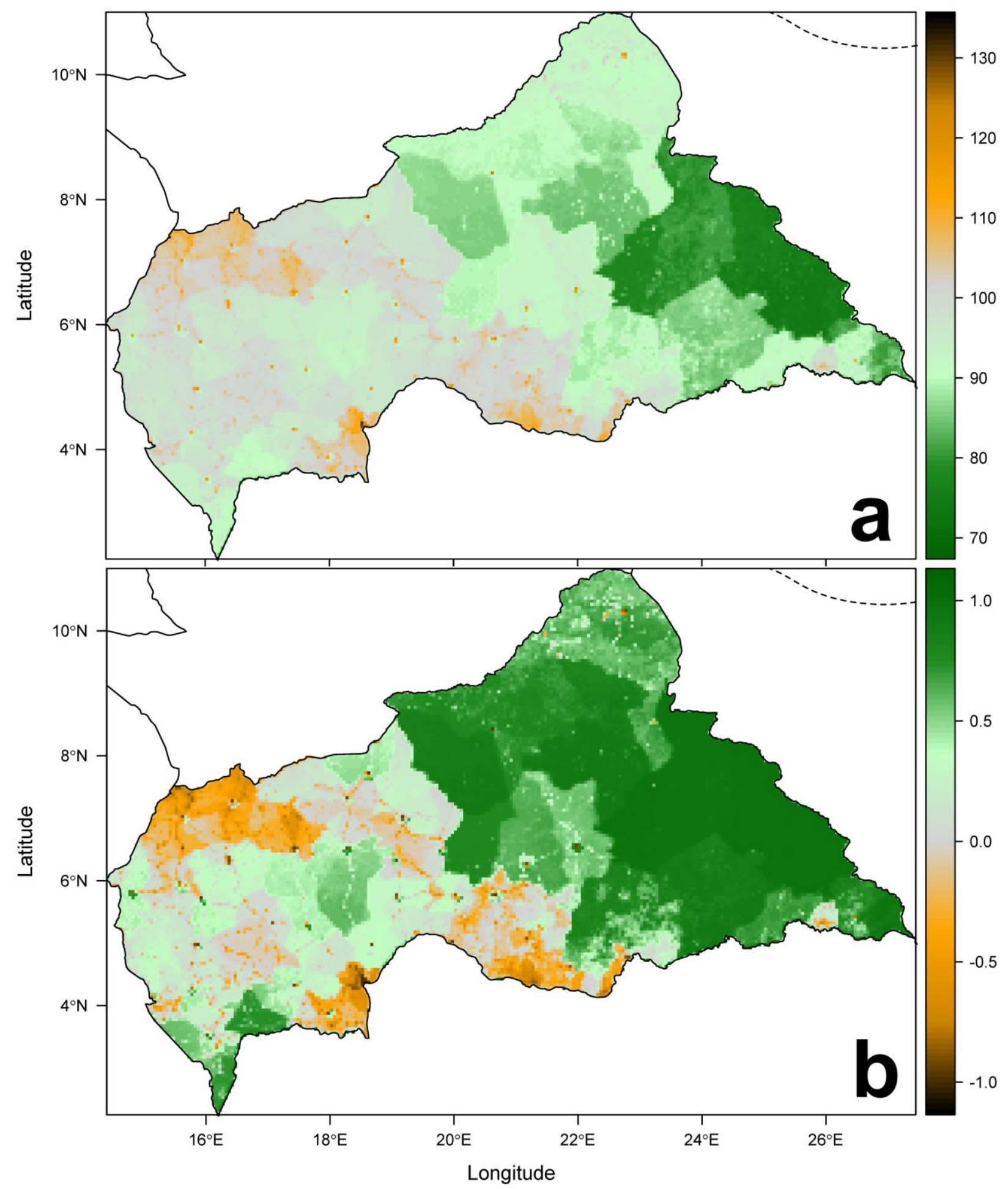

Figure 9: Mean DSR (a) and CSDI (b) in the Central African Republic for 2000 - 2010. In contrast to Figure 8 , both metrics are visualized here using identical color scales. 


\section{Discussion}

This paper adds to a series of studies on large-scale vegetation dynamics with a focus on the relationship between anthropogenic demand and ecosystem supply of NPP. Humans rely directly on the supply of NPP through the consumption of crops and use of wood for fuel and construction, and indirectly through animal products. This reliance creates demand that drives many of the ecological changes occurring in the drylands of Africa. Africa accounts for roughly 20\% of global NPP [99] and more than half of its land surface can be classified as a dryland system, whose importance in the terrestrial carbon cycle has recently been identified $[92,93]$. The integrated analysis of the supply and demand of NPP allows the identification of areas at risk of consuming more resources than are available, either presently or in future scenarios [94]. Evaluating socioecological impacts through isolated disciplinary analysis provides monocular views of a complex system that requires an integrated approach. However, such an approach needs to be reasonably accurate to represent reality, and follow Occam's razor by being simple enough to be easily understood and widely applicable. It is a difficult balancing act. The method proposed here is only the first step in quantifying the effect of human consumption on ecosystems using methods the integrate disparate methods.

\subsection{Past and present perspectives}

There is a long history of studies that attempted to quantify the impact of human consumption on ecosystems. Human consumption of primary production was first investigated by Whittaker and Likens [95] as a way to quantify human impact on the biosphere. They estimated that humans consumed, through the harvest of food and wood, only about $8 \%$ of the global primary production. Vitousek, Ehrlich [96] in their more refined calculations used a three-tiered estimation (low, intermediate, high) in calculating human appropriation of NPP. Their low estimate (3.2\%) represented the NPP humans consume directly; the intermediate estimate (30.7\%) included the terrestrial NPP dedicated for human use (e.g. croplands); the high estimate (38.8\%) includes terrestrial productive capacity lost as a result of anthropogenic land use and cover change. Each of their higher level estimate included variables from the preceding lower level estimate.

Rojstaczer, Sterling [97] reanalyzed the intermediate estimate from Vitousek, Ehrlich [96] and came to a mean estimate of $32 \%$; though their large error margin of 10 to $55 \%$ results from authors not fully taking advantage of publicly available data, and assuming that every published datum, regardless of methodology and date, carries equal weight $[98,99]$. Imhoff and Bounoua [100] estimated annual global demand by aggregating NPP required to generate various products consumed by humans and biomass lost in harvest and processing. They found that in 1995, the global human population had a total carbon demand of $11.5 \mathrm{PgC}$ or around $20 \%$ of global NPP supply of 56.8 PgC.

Work done by Haberl [101] shifted the discussion towards human impacts on undisturbed landscapes, i.e. areas devoid of human activity. This method, termed Human Appropriation of Net Primary Production (HANPP), involved modeling the NPP of potential natural vegetation using a dynamic global vegetation model (DGVM), which gave a baseline NPP of landscapes driven purely by climate and unaltered by humans $\left(\mathrm{NPP}_{0}\right)$. Then, the NPP of actual vegetation (NPP act) is calculated using satellite derived estimates such as MOD17 and subtracted from $\mathrm{NPP}_{0}$ to yield HANPP resulting from land use and land conversion (HANPP luc). Finally, HANPP $_{\text {luc }}$ is combined with biomass that is harvested or destroyed during/after harvest $\left(\mathrm{HANPP}_{\text {harv }}\right)$ to yield the final HANPP metric [102]. Using this approach, Haberl, Erb [103] and Krausmann, Erb [104] produced estimates of $29 \%$ and $25 \%$, respectively, of the global aboveground NPP that is impacted by humans through harvest, land use and cover change, and soil degradation.

HANPP is posited to be directly related to land use patterns because it depends on both socioeconomic and natural processes [105]. Land use patterns are linked to activities that result in the production of goods for human consumption. For example, a forest is cleared to make way for agricultural land, thereby natural land cover with high potential NPP is replaced with a low-NPP land use category that supplies products for human consumption. The value of HANPP can be negative because it is calculated in relation to potential NPP. This 
is the case in areas with low (or no) natural NPP that are heavily irrigated using groundwater to create agricultural land (e.g. in the Arabian Peninsula). HANPP thus provides information about how human activities have altered pristine landscapes.

In contrast, the approach described in this paper indicates fraction of carbon in a landscape, regardless of pristineness, that is in/directly appropriated by humans. However, an important limitation of the DSR/CSDI is that it assumes NPP flows are constrained by the local population distribution and does not take into consideration NPP flows connected to international trade. This constraint is indeed applicable to several, if not most, rural communities in Africa, however, the paradigm is shifting and human-environment systems on the continent are becoming increasingly telecoupled over large distances [106]. Another limitation of DSR/CSDI is that it does not account for the drivers of demand or include a technology factor that factors in advancements in agricultural productivity.

\subsection{Methodological caveats and practicalities}

The NPP-based framework presented here must not be construed as a famine early warning system. This is because the dynamics of famines invariably depend upon institutional involvement (or lack thereof). Instead, DSR/CSDI can be considered as a "long-term warning system" as it integrates processes that affect human well-being across longer time scales. For example, one of the factors that could lead to a famine is the lack of infrastructure which prevents food from flowing from areas of surplus to areas of deficit [107]. Thus, an important utility of the demand-supply balance lies in helping identify areas where, in the long-term, demand can surpass supply and which could require better investments, for instance, in infrastructure, transportation, assistance in land rehabilitation, etc. A second practicality of the demand-supply balance is its linkage to population-driven resource-use. An increasing human population is not necessarily something negative. Indeed, for some countries, particularly those with developed economies, a certain rate of positive population growth is essential for economic growth [108]. However, when this growth is assessed from the perspective of resource-use and the demands exerted by humans on ecosystem supply, a different picture emerges that is linked to, among other things, the rate of increase in demand.

Qualitative data, such as surveys at the household (or even individual) level, which provide valuable information about fine-scale patterns of human-ecosystem interaction, are seldom integrated with biophysical datasets. An important factor that influences the balance between supply and demand is caloric requirement. In this sense, gridded population data, such as the one presented in this paper, will prove to be even more useful. High resolution gridded population data that accounts for different radiative forcing and socioeconomic scenarios will allow the linking the caloric requirement of a population with availability. Data on average dietary energy requirement, e.g. 2,090 kcal per person per day in Southern Africa, could be further fine-tuned to local levels using census and survey data. Then, applied to time series gridded population data to get a better estimate of caloric demand across space and time.

There are signs that the scientific community maybe heading in the direction of estimating caloric value of a landscape. For example, Cassidy, West [65] has shown that it is possible to spatialize the proportion of global agricultural yield that is used for food or feed on a per calorie basis. This allows for a direct comparison of how many people could be sustained in a particular area. Additionally, there is a need for spatially explicit network analysis, such as the type used in geographic information systems, to map NPP flows from producing areas to consuming areas through road networks. This is necessary to allow for flexible limits in the demandsupply framework so that factors such as market access and rural-urban flows could be taken into account.

Overall, the DSR was $86 \%$ across the drylands of Africa during the first decade of the $21^{\text {st }}$ century [3]. This balance was high in some regions such as the Sahel, a climatically sensitive region with high anthropogenic activity. DSR in the Sahel is around 95\% in the rural areas and up to $150 \%$ in the urban areas (Figure 8 a). CSDI was also highly variable across the region (Figure $8 \mathrm{~b}$ ) with low values of around -0.5 and high of -0.98 . Annual increase in NPP demand in the Sahel was 2.2\% between 2000 and 2011 [2]. This rapidly increasing 
demand for food, fuel and feed driven by population growth makes this region in particular vulnerable to climatic variability that may alter the per capita availability of NPP. There is risk that ecosystems may not be able to provide for the region's humans and livestock without a corresponding increase in NPP supply. This underscores the importance of accounting for the balance between supply and demand of NPP because neither quantity provides a complete picture by itself.

\subsection{Advancement of satellite-derived G/NPP}

Understanding the environmental constraints on primary production in drylands is an important step to improve estimates of NPP supply and better assess the balance between supply and demand. The supply of primary production in drylands is primarily controlled by water availability. This important factor is regulated by two processes, plant available water and vapor pressure deficit, that work in unison (increase in one, decrease in the other) during the greening and browning phases [31]. However, knowledge about their magnitude, spatial, temporal variability and seasonal process (e.g. during dry season) is incomplete [109]. This is a crucial knowledge gap, particularly in the wake of rising atmospheric $\mathrm{CO}_{2}$ concentrations and recurrent droughts [110].

As mentioned in section 2.2.1, the use of static values for maximum LUE $\left(\varepsilon_{\max }\right)$ to represent hypothetical biome-specific ideal conditions introduces errors into the modeling of GPP, and by extension, NPP. A possible remedy is the derivation of lies in deriving $\varepsilon_{\max }$ directly from the global network of eddy covariance flux towers under prevailing climatic conditions [111]. This approach creates an inherently dynamic product representative of reality where optimum LUE $\left(\varepsilon_{\mathrm{opt}}\right)$ is variable between and within biomes instead of each biome being assigned a single arbitrary $\varepsilon_{\max }$. The improved GPP estimates using $\varepsilon_{\mathrm{opt}}$ can be used to derived NPP using gridded estimates of autotrophic respiration $\left(\mathrm{R}_{\mathrm{a}}\right)$ derived using Earth observation. Recently, Jägermeyr, Gerten [112] found that MODIS land surface temperature (LST) and the enhanced vegetation index (EVI) were able to explain $62 \%$ of the variability in ecosystem respiration $\left(\mathrm{R}_{\mathrm{e}}\right)$ across most global biomes. It has been previously reported that the components of $R_{e}$, which are $R_{a}$ and $R_{h}$ (heterotrophic respiration), may have a constant correlation [113]. However, this hypothesis needs to be tested across multiple biomes on different continents in order for a robust dataset of the $R_{a}-R_{h}$ relationship to be developed. In that sense, daily 1-km LST from MODIS (MOD11A1/MYD11A1) holds considerable potential for the estimation of $\mathrm{R}_{\mathrm{e}}$ at global scales.

Generally, the inclusion of LST allows for a GPP model to capture heat stress, however the direct effect of LST (i.e. actual canopy temperature) on photosynthesis is rather unclear [114]. The mechanism through which high canopy temperatures affect photosynthesis is not well understood. There is evidence that decrease in photosynthesis at high canopy temperatures is caused by high leaf-to-air vapor pressure deficit (VPD) than by direct negative effects of temperature on photosynthetic metabolism [115]. Indeed, the physiological response of vegetation is strongly linked to the terrestrial surface energy balance [116, 117]. There is also some indication that increasing LST over a vegetation canopy is linked to looming drought due to decrease in latent heat flux (stomatal closure) and increase in sensible heat flux [118].

According to Fick's first law of diffusion, plants lose water to the atmosphere with increasing VPD if the stomata remain open [119]. Therefore, it is reasonable to assume that there will be a decrease in transpiration with rising VPD because plants will opt to conserve water. This means that there will be a reduction in the amount of energy leaving the canopy in the form of latent heat. Because energy fluxes must balance, there will be a corresponding increase in sensible heat that raises leaf temperature. It is plausible that this increase in sensible heat manifests as increase in LST. As leaf temperature increases, a weakening of the biochemical processes that occur during photosynthesis and can further reduce GPP. Thus, plant physiological response to increased VPD may trigger a process that is captured in the remotely-sensed LST signal.

The launch of new Earth observing satellites with open access data policies, the proliferation of advanced machine learning algorithms, and the availability of cloud computing platforms have created opportunities for 
the improvement of land cover data in the complex landscapes of Africa's drylands [120-123]. Indeed, one of the problems associated with the MOD17 LUE approach is the poor quality of land cover data to which BPLUT assigned $\varepsilon_{\max }$ values $[4,60,124]$. With improved land cover data, better characterization of land cover data should allow for a better understanding of the distribution of LUE values between and within biomes.

\subsubsection{Importance of capacity building in improving G/NPP}

It is widely recognized that there is a lack of field data on carbon fluxes in Africa to validate satellite-based models because the continent has the least number of eddy covariance flux towers relative to its size [125]. One potential solution to this problem lies in capacity building, which produces three favorable outcomes. First, it eliminates the need for scientists to only rely on data that was collected in the past as their sole sources of validation. Second, it allows for a shared understanding of the principles and processes involved in ecosystem ecology, and, in combination with local knowledge, sets the foundation for locally-led projects. This is important because it provides agency for local scientists to enhance and apply their expertise, which in turn disincentives reliance on external actors. Finally, it creates a mutually beneficial ecosystem based on an exchange of ideas, and that fosters collaboration and innovation.

\subsection{The way forward}

The DSR/CSDI is somewhat similar to the internal flows in intraregional connectedness described in Dorninger, Abson [126]. In some measure, this represents non-industrialized, self-sufficient rural systems and moderately industrialized urban systems. Nonetheless, there is currently no metric that accounts for biomass flows linked to human consumption and their impact on ecosystems in a spatially explicit (i.e. gridded) and temporally consistent (i.e. annual time series) manner. Most of the existing methods, including the one described here, suffer from one or more of the following: (1) they aggregate flows at national or subnational levels, (2) they represent a single time period or a series or irregular time slices, (3) the impact of certain human activities (such as livestock) on ecosystems is not included, (4) they do not account for the role of teleconnections such as imports/exports and land grabs. Indeed, a comprehensive, integrated approach is essential to further assess the factors driving this complex balance, particularly in the wake of climate change. Only through innovative transdisciplinary analysis (e.g. Johansson and Abdi [127]) involving enhanced synthesis of biophysical, social, ecological and economic data can we develop improved assessments of the impacts of humans on ecosystems. 


\section{References}

1. $\quad$ Abdi, A.M., Primary Production in African Drylands: Quantifying Supply and Demand Using Earth Observation and Socio-ecological Data, in Department of Physical Geography and Ecosystem Science. 2017, Lund University: Lund, Sweden. p. 180.

2. Abdi, A.M., J. Seaquist, D.E. Tenenbaum, L. Eklundh, and J. Ardo, The supply and demand of net primary production in the Sahel. Environmental Research Letters, 2014. 9(9): p. 094003.

3. Abdi, A.M., A. Vrieling, G.T. Yengoh, A. Anyamba, J.W. Seaquist, C.C. Ummenhofer, and J. Ardö, The El Niño - La Niña cycle and recent trends in supply and demand of net primary productivity in African drylands. Climatic Change, 2016. 138(1): p. 111-125.

4. Abdi, A.M., N. Boke-Olén, H. Jin, L. Eklundh, T. Tagesson, V. Lehsten, and J. Ardö, First assessment of the plant phenology index (PPI) for estimating gross primary productivity in African semi-arid ecosystems. International Journal of Applied Earth Observation and Geoinformation, 2019. 78: p. 249-260.

5. Templeton, A., Out of Africa again and again. Nature, 2002. 416(6876): p. 45-51.

6. Smith, A., An Inquiry into the Nature and Causes of the Wealth of Nations. 1776, London: W. Strahan and T. Cadell.

7. Lees, S.H. and D.G. Bates, The Origins of Specialized Nomadic Pastoralism: A Systemic Model. American Antiquity, 1974. 39(2): p. 187-193.

8. $\quad$ Nicholson, S.E., Dryland Climatology. 2011: Cambridge University Press.

9. Batterbury, S., Landscapes of Diversity: A Local Political Ecology of Livelihood Diversification in SouthWestern Niger. Ecumene, 2001. 8(4): p. 437-464.

10. de Haan, A., K. Brock, and N. Coulibaly, Migration, Livelihoods and Institutions: Contrasting Patterns of Migration in Mali. The Journal of Development Studies, 2002. 38(5): p. 37-58.

11. Dovie, D.B.K., Rural economy and livelihoods from the non-timber forest products trade. Compromising sustainability in southern Africa? International Journal of Sustainable Development \& World Ecology, 2003. 10(3): p. 247-262.

12. Masih, I., S. Maskey, F.E.F. Mussá, and P. Trambauer, A review of droughts on the African continent: a geospatial and long-term perspective. Hydrol. Earth Syst. Sci., 2014. 18(9): p. 3635-3649.

13. Sen, A., Development as Freedom. 1999, New York, NY: Anchor Books.

14. Caldwell, J.C., Demographic aspects of drought: An examination of the African drought of 1970-74. African Environment Special Report, 1977. 6: p. 93-100.

15. Degefu, W., Some aspects of meteorological drought in Ethiopia, in Drought and Hunger in Africa, M.H. Glantz, Editor. 1988, Cambridge University Press: Cambridge, UK.

16. Seaman, J., Famine Mortality in Africa. IDS Bulletin, 1993. 24(4): p. 27-32.

17. Samatar, A.I., The State and Rural Transformation in Northern Somalia, 1884-1986. 1989, Madison, Wisconsin: University of Wisconsin Press.

18. Ahmed, I.I. and R.H. Green, The Heritage of War and State Collapse in Somalia and Somaliland: Local-Level Effects, External Interventions and Reconstruction. Third World Quarterly, 1999. 20(1): p. 113-127.

19. Tschakert, P., R. Sagoe, G. Ofori-Darko, and S.N. Codjoe, Floods in the Sahel: an analysis of anomalies, memory, and anticipatory learning. Climatic Change, 2010. 103(3): p. 471-502.

20. Barrett, C.B. and J.B. Upton, Food Security and Sociopolitical Stability in Sub-Saharan Africa, in Food Security and Sociopolitical Stability. 2013, Oxford University Press: New York, NY.

21. Budyko, M.I., Climate and life. English ed. / edited by David H. Miller ed, ed. D.H. Miller. 1974, New York, NY: Academic Press. 508.

22. Funk, C., P. Peterson, M. Landsfeld, D. Pedreros, J. Verdin, S. Shukla, ... J. Michaelsen, The climate hazards infrared precipitation with stations - a new environmental record for monitoring extremes. Scientific Data, 2015. 2: p. 150066.

23. Mu, Q., M. Zhao, and S.W. Running, Improvements to a MODIS global terrestrial evapotranspiration algorithm. Remote Sensing of Environment, 2011. 115(8): p. 1781-1800.

24. Tucker, C.J., C. Vanpraet, E. Boerwinkel, and A. Gaston, Satellite remote sensing of total dry matter production in the Senegalese Sahel. Remote Sensing of Environment, 1983. 13(6): p. 461-474.

25. Prince, S.D., Satellite remote sensing of primary production: comparison of results for Sahelian grasslands 1981-1988. International Journal of Remote Sensing, 1991. 12(6): p. 1301-1311.

26. Verhoef, A., S.J. Allen, H.A.R. Bruin, C.M.J. Jacobs, and B.G. Heusinkveld, Fluxes of carbon dioxide and water vapour from a Sahelian savanna. Agric For Meteorol., 1996. 80.

27. Moncrieff, J.B., B. Monteny, A. Verhoef, T. Friborg, J. Elbers, P. Kabat, . . J.D. Taupin, Spatial and temporal variations in net carbon flux during HAPEX-Sahel. Journal of Hydrology, 1997. 188: p. 563-588.

28. Nicholson, S.E., C.J. Tucker, and M. Ba, Desertification, drought, and surface vegetation: An example from the West African Sahel. Bulletin of the American Meteorological Society, 1998. 79(5): p. 815-830. 
29. Hickler, T., L. Eklundh, J.W. Seaquist, B. Smith, J. Ardö, L. Olsson, . . M. Sjöström, Precipitation controls Sahel greening trend. Geophysical Research Letters, 2005. 32(21): p. L21415.

30. Sjöström, M., J. Ardö, A. Arneth, N. Boulain, B. Cappelaere, L. Eklundh, . . Y. Nouvellon, Exploring the potential of MODIS EVI for modeling gross primary production across African ecosystems. Remote Sensing of Environment, 2011. 115(4): p. 1081-1089.

31. Abdi, A.M., N. Boke-Olén, D.E. Tenenbaum, T. Tagesson, B. Cappelaere, and J. Ardö, Evaluating Water Controls on Vegetation Growth in the Semi-Arid Sahel Using Field and Earth Observation Data. Remote Sensing, 2017. 9(3): p. 294.

32. Merbold, L., J. Ardö, A. Arneth, R. Scholes, Y. Nouvellon, A. De Grandcourt, . . N. Brueggemann, Precipitation as driver of carbon fluxes in 11 African ecosystems. Biogeosciences, 2009. 6: p. 1027-1041.

33. Cook, K.H., Generation of the African Easterly Jet and Its Role in Determining West African Precipitation. Journal of Climate, 1999. 12(5): p. 1165-1184.

34. Dingman, S.L., Physical Hydrology: Third Edition. 2015: Waveland Press.

35. Anderson, D.B., Relative Humidity or Vapor Pressure Deficit. Ecology, 1936. 17(2): p. $277-282$.

36. Battisti, D.S. and R.L. Naylor, Historical Warnings of Future Food Insecurity with Unprecedented Seasonal Heat. Science, 2009. 323(5911): p. 240-244.

37. Johnson, P.L. and J.J. Kelley, Dynamics of Carbon Dioxide and Productivity in an Arctic Biosphere. Ecology, 1970. 51(1): p. 73-80.

38. Szarek, S.R. and R.M. Woodhouse, Ecophysiological studies of Sonoran Desert plants. Oecologia, 1977. 28(4): p. 365-375.

39. Baldocchi, D.D., B.B. Hincks, and T.P. Meyers, Measuring Biosphere-Atmosphere Exchanges of Biologically Related Gases with Micrometeorological Methods. Ecology, 1988. 69(5): p. 1331-1340.

40. Schlesinger, W.H., Biogeochemistry: an analysis of global change. 1997: Academic press.

41. Lieth, H., Versuch einer kartographischen Darstellung der Produktivitat der Pflanzendecke auf der Erde. Geographisches Taschenbuch, 1964. 65: p. 72-80.

42. Lieth, H., Uber die Primarproduktion der pflanzendecke der Erde. Angewandte Botanik, 1972. 46: p. 1-37.

43. Rouse, J.W., R.H. Haas, D.W. Deering, and J.A. Schell, Monitoring the vernal advancement and retrogradation (green wave effect) of natural vegetation. 1973, Remote Sensing Center, Texas A\&M University: College Station, Texas. p. 44-47.

44. Lieth, H. and R.H. Whittaker, Primary Productivity of the Biosphere. Ecological Studies. 1975, Berlin: Springer.

45. Lieth, H., Primary Production: Terrestrial Ecosystems. Human Ecology, 1973. 1(4): p. $303-332$.

46. Monteith, J.L., Solar radiation and productivity in tropical ecosystems. Journal of Applied Ecology, 1972. 9(3): p. 747-766.

47. Monteith, J.L. and C.J. Moss, Climate and the efficiency of crop production in Britain. Philosophical Transactions of the Royal Society of London. B, Biological Sciences, 1977. 281(980): p. 277-294.

48. Tucker, C.J., B.N. Holben, J.H. Elgin, and J.E. McMurtrey, Remote sensing of total dry-matter accumulation in winter wheat. Remote Sensing of Environment, 1981. 11: p. 171-189.

49. Running, S.W., Global primary production from terrestrial vegetation: Estimates integrating satellite remote sensing and computer simulation technology. Science of the total environment, 1986. 56: p. 233-242.

50. Monteith, J., Does light limit crop production?, in Physiological Processes Limiting Plant Productivity, C. Johnson, Editor. 1981, Butterworth: London. p. 23-38.

51. Running, S.W., C.O. Justice, V. Salomonson, D. Hall, J. Barker, Y.J. Kaufmann, . . D. Carneggie, Terrestrial remote sensing science and algorithms planned for EOS/MODIS. International Journal of Remote Sensing, 1994. 15(17): p. 3587-3620.

52. Running, S.W., P.E. Thornton, R.R. Nemani, and J.M. Glassy, Global terrestrial gross and net primary productivity from the Earth Observing System, in Methods in Ecosystem Science, O.E. Sala, H.A. Mooney, and R.W. Howarth, Editors. 2000, Springer-Verlag, New York. p. 44-57.

53. Running, S.W., D.D. Baldocchi, D.P. Turner, S.T. Gower, P.S. Bakwin, and K.A. Hibbard, A Global Terrestrial Monitoring Network Integrating Tower Fluxes, Flask Sampling, Ecosystem Modeling and EOS Satellite Data. Remote Sensing of Environment, 1999. 70(1): p. 108-127.

54. Turner, D.P., W.D. Ritts, W.B. Cohen, S.T. Gower, S.W. Running, M. Zhao, ... S.R. Saleska, Evaluation of MODIS NPP and GPP products across multiple biomes. Remote Sensing of Environment, 2006. 102(3): p. 282-292.

55. Running, S.W., R.R. Nemani, F.A. Heinsch, M. Zhao, M. Reeves, and H. Hashimoto, A Continuous SatelliteDerived Measure of Global Terrestrial Primary Production. BioScience, 2004. 54(6): p. 547-560.

56. Heinsch, F.A., M. Reeves, C. Bowker, P. Votava, S. Kang, C. Milesi, ... S. Running, GPP and NPP (MOD17A2/A3) Products NASA MODIS Land Algorithm. MOD17 User's Guide, 2003: p. 1-57.

57. Sjöström, M., M. Zhao, S. Archibald, A. Arneth, B. Cappelaere, U. Falk, .. . J. Ardö, Evaluation of MODIS gross primary productivity for Africa using eddy covariance data. Remote Sensing of Environment, 2013. 131: p. 275-286. 
58. Tagesson, T., J. Ardö, B. Cappelaere, L. Kergoat, A. Abdi, S. Horion, and R. Fensholt, Modelling spatial and temporal dynamics of gross primary production in the Sahel from earth-observation-based photosynthetic capacity and quantum efficiency. Biogeosciences, 2017. 14(5): p. 1333-1348.

59. Running, S.W. and M. Zhao, User's Guide ver. 3.0: Daily GPP and Annual NPP (MOD17A2/A3) Products. NASA Earth Observing System MODIS Land Algorithm. 2015, Numerical Terradynamics Simulation Group: Missoula, Montana.

60. Zhao, M., S. Running, F.A. Heinsch, and R. Nemani, MODIS-derived terrestrial primary production, in Land Remote Sensing and Global Environmental Change, B. Ramachandran, C.O. Justice, and M.J. Abrams, Editors. 2011, Springer: New York. p. 635-660.

61. Linard, C., M. Gilbert, R.W. Snow, A.M. Noor, and A.J. Tatem, Population Distribution, Settlement Patterns and Accessibility across Africa in 2010. PLoS ONE, 2012. 7(2): p. e31743.

62. Arino, O., J.J. Ramos Perez, V. Kalogirou, S. Bontemps, P. Defourny, and E. Van Bogaert, Global Land Cover Map for 2009 (GlobCover 2009). 2012, PANGAEA.

63. Shapouri, S. and S.L. Rosen, Food Security Assessment: Why Countries Are at Risk. 1999, U.S. Department of Agriculture: Washington, DC.

64. Elbehri, A., J. Kaminski, S. Koroma, M. Iafrate, and M. Benali, West Africa food systems: An overview of trends and indicators of demand, supply, and competitiveness of staple food value chains, in Rebuilding West Africa's Food Potential, A. Elbehri, Editor. 2013, FAO/IFAD.

65. Cassidy, E.S., P.C. West, J.S. Gerber, and J.A. Foley, Redefining agricultural yields: from tonnes to people nourished per hectare. Environmental Research Letters, 2013. 8(3): p. 034015.

66. Fox, L., Are African Households Heterogeneous Agents? , in IMF Working Paper. 2015, International Monetary Fund: Washignton, DC.

67. Halweil, B., Home Grown: The Case For Local Food In A Global Market. 2002, Worldwatch Institute.

68. Obayelu, A.E. Assessment of Food Reserves, Markets, Trade, and Regional Integration Systems in SubSaharan Africa: Are these effective pathways to food security? in Increasing agricultural productivity and enhancing food security in Africa. 2011. Addis Ababa, Ethiopia: International Food Policy Research Institute.

69. Jones, P.G. and P.K. Thornton, Croppers to livestock keepers: livelihood transitions to 2050 in Africa due to climate change. Environmental Science \& Policy, 2009. 12(4): p. 427-437.

70. Ickowicz, A., V. Ancey, C. Corniaux, G. Duteurtre, R. Poccard-Chappuis, I. Touré, ... A. Wane. Croplivestock production systems in the Sahel - increasing resilience for adaptation to climate change and preserving food security. in Building resilience for adaptation to climate change in the agriculture sector. 2012. Rome, Italy: Food and Agriculture Organization of the United Nations (FAO).

71. Knips, V., Review of the livestock sector in the Horn of Africa (IGAD countries), in Livestock Sector Report. 2004, Food and Agriculture Organization of the United Nations: Rome, Italy.

72. Sperling, L., The adoption of camels by Samburu cattle herders. Nomadic Peoples, 1987(23): p. 1-17.

73. Blench, R., The Expansion and Adaptation of Fulbe Pastoralism to Subhumid and Humid Conditions in Nigeria (L'expansion et l'adaptation du pastoralisme peul aux conditions climatiques humides et subhumides du Nigeria). Cahiers D'Études Africaines, 1994. 34(133/135): p. 197-212.

74. Hiemstra-van der Horst, G. and A.J. Hovorka, Fuelwood: The "other" renewable energy source for Africa? Biomass and Bioenergy, 2009. 33(11): p. 1605-1616.

75. Pires, M., The Spatial Polarization of Woodfuel Supply and Demand in Senegal. African Geographical Review, 2003. 22(1): p. 29-47.

76. Maiga, A., G. Chen, Q. Wang, and J. Xu, Renewable energy options for a Sahel country: Mali. Renewable and Sustainable Energy Reviews, 2008. 12(2): p. 564-574.

77. Hassan, R., G. Hertzler, and J.K.A. Benhin, Depletion of forest resources in Sudan: Intervention options for optimal control. Energy Policy, 2009. 37(4): p. 1195-1203.

78. van der Plas, R.J. and M.A. Abdel-Hamid, Can the woodfuel supply in sub-Saharan Africa be sustainable? The case of N’Djaména, Chad. Energy Policy, 2005. 33(3): p. 297-306.

79. Bailis, R., R. Drigo, A. Ghilardi, and O. Masera, The carbon footprint of traditional woodfuels. Nature Climate Change, 2015. 5(3): p. 266-272.

80. Breman, H. and J.-J. Kessler, The Distribution and Canopy Cover of Woody Species, in Woody Plants in AgroEcosystems of Semi-Arid Regions: with an Emphasis on the Sahelian Countries. 1995, Springer Berlin Heidelberg: Berlin, Heidelberg. p. 4-53.

81. FAOSTAT, FAO Statistical Databases. 2015, Food and Agriculture Organization of the United Nations: Rome, Italy.

82. Zulu, L.C., The forbidden fuel: Charcoal, urban woodfuel demand and supply dynamics, community forest management and woodfuel policy in Malawi. Energy Policy, 2010. 38(7): p. 3717-3730.

83. Andela, N. and G.R. van der Werf, Recent trends in African fires driven by cropland expansion and El Nino to La Nina transition. Nature Clim. Change, 2014. 4(9): p. 791-795.

84. Boke-Olén, N., A.M. Abdi, O. Hall, and V. Lehsten, High-resolution African population projections from radiative forcing and socio-economic models, 2000 to 2100. Scientific Data, 2017. 4: p. 160130. 
85. Fetzel, T., M. Niedertscheider, H. Haberl, F. Krausmann, and K.-H. Erb, Patterns and changes of land use and land-use efficiency in Africa 1980-2005: an analysis based on the human appropriation of net primary production framework. Regional Environmental Change, 2015: p. 1-14.

86. Knox, J., T. Hess, A. Daccache, and T. Wheeler, Climate change impacts on crop productivity in Africa and South Asia. Environmental Research Letters, 2012. 7(3): p. 034032.

87. Schlenker, W. and D.B. Lobell, Robust negative impacts of climate change on African agriculture. Environmental Research Letters, 2010. 5(1): p. 014010.

88. Thornton, P.K., P.G. Jones, P.J. Ericksen, and A.J. Challinor, Agriculture and food systems in sub-Saharan Africa in $a 4^{\circ} \mathrm{C}+$ world. Vol. 369. 2011. 117-136.

89. Jones, P.G. and P.K. Thornton, The potential impacts of climate change on maize production in Africa and Latin America in 2055. Global Environmental Change, 2003. 13(1): p. 51-59.

90. Olsson, L., An Integrated Study of Desertification, in Department of Physical Geography and Ecosystem Science. 1985, Lund University: Lund, Sweden. p. 170.

91. Campbell, M.M., J. Casterline, F. Castillo, A. Graves, T.L. Hall, J.F. May, ... E.M. Zulu, Population and climate change: who will the grand convergence leave behind? The Lancet Global Health, 2014. 2(5): p. e253e254.

92. Poulter, B., D. Frank, P. Ciais, R.B. Myneni, N. Andela, J. Bi, . . G.R. van der Werf, Contribution of semiarid ecosystems to interannual variability of the global carbon cycle. Nature, 2014. 509(7502): p. 600-603.

93. Ahlström, A., M.R. Raupach, G. Schurgers, B. Smith, A. Arneth, M. Jung, ... N. Zeng, The dominant role of semi-arid ecosystems in the trend and variability of the land CO2 sink. Science, 2015. 348(6237): p. 895-899.

94. Sallaba, F., S. Olin, K. Engström, A.M. Abdi, N. Boke-Olén, V. Lehsten, . . J.W. Seaquist, Future supply and demand of net primary production in the Sahel. Earth Syst. Dynam., 2017. 8(4): p. 1191-1221.

95. Whittaker, R. and G. Likens, Primary production: The biosphere and man. Human Ecology, 1973. 1(4): p. 357-369.

96. Vitousek, P.M., P.R. Ehrlich, A.H. Ehrlich, and P.A. Matson, Human Appropriation of the Products of Photosynthesis. BioScience, 1986. 36(6): p. 368-373.

97. Rojstaczer, S., S.M. Sterling, and N.J. Moore, Human appropriation of photosynthesis products. Science, 2001. 294(5551): p. 2549-2552.

98. Field, C.B., Sharing the Garden. Science, 2001. 294(5551): p. 2490-2491.

99. Haberl, H., F. Krausmann, K.H. Erb, and N.B. Schulz, Human appropriation of net primary production. Science, 2002. 296(5575): p. 1968-1969.

100. Imhoff, M.L. and L. Bounoua, Exploring global patterns of net primary production carbon supply and demand using satellite observations and statistical data. Journal of geophysical research, 2006. 111(D22): p. D22S12.

101. Haberl, H., Human Appropriation of Net Primary Production as an Environmental Indicator: Implications for Sustainable Development. Ambio, 1997. 26(3): p. 143-146.

102. Haberl, H., K.-H. Erb, and F. Krausmann, Human Appropriation of Net Primary Production: Patterns, Trends, and Planetary Boundaries. Annual Review of Environment and Resources, 2014. 39(1): p. 363-391.

103. Haberl, H., K.H. Erb, F. Krausmann, V. Gaube, A. Bondeau, C. Plutzar, . . M. Fischer-Kowalski, Quantifying and mapping the human appropriation of net primary production in earth's terrestrial ecosystems. Proceedings of the National Academy of Sciences, 2007. 104(31): p. 12942-12947.

104. Krausmann, F., K.-H. Erb, S. Gingrich, H. Haberl, A. Bondeau, V. Gaube, . . T.D. Searchinger, Global human appropriation of net primary production doubled in the 20th century. Proceedings of the National Academy of Sciences, 2013.

105. Krausmann, F., H. Haberl, K.H. Erb, M. Wiesinger, V. Gaube, and S. Gingrich, What determines geographical patterns of the global human appropriation of net primary production? Journal of Land Use Science, 2009. 4(1-2): p. 15-33.

106. Liu, J., V. Hull, M. Batistella, R. DeFries, T. Dietz, F. Fu, . . C. Zhu, Framing Sustainability in a Telecoupled World. Ecology and Society, 2013. 18(2).

107. Olsson, L., On the Causes of Famine: Drought, Desertification and Market Failure in the Sudan. Ambio, 1993. 22(6): p. 395-403.

108. Harper, S., Economic and social implications of aging societies. Science, 2014. 346(6209): p. 587.

109. D. Stock, W., Plants anticipating rain - a challenge for modelling climate change impacts. New Phytologist, 2017. 213(2): p. 475-477.

110. Dai, A., Increasing drought under global warming in observations and models. Nature Clim. Change, 2013. 3(1): p. 52-58.

111. Madani, N., J.S. Kimball, and S.W. Running, Improving Global Gross Primary Productivity Estimates by Computing Optimum Light Use Efficiencies Using Flux Tower Data. Journal of Geophysical Research: Biogeosciences, 2017. 122(11): p. 2939-2951.

112. Jägermeyr, J., D. Gerten, W. Lucht, P. Hostert, M. Migliavacca, and R. Nemani, A high-resolution approach to estimating ecosystem respiration at continental scales using operational satellite data. Global Change Biology, 2014. 20(4): p. 1191-1210. 
113. Bond-Lamberty, B., C. Wang, and S.T. Gower, A global relationship between the heterotrophic and autotrophic components of soil respiration? Global Change Biology, 2004. 10(10): p. 1756-1766.

114. Wu, C., J.W. Munger, Z. Niu, and D. Kuang, Comparison of multiple models for estimating gross primary production using MODIS and eddy covariance data in Harvard Forest. Remote Sensing of Environment, 2010. 114(12): p. 2925-2939.

115. Lloyd, J. and G.D. Farquhar, Effects of rising temperatures and [CO $<\mathrm{sub}>2</$ sub $>$ ] on the physiology of tropical forest trees. Philosophical Transactions of the Royal Society B: Biological Sciences, 2008. 363(1498): p. 1811-1817.

116. Chapin, F.S., P.A. Matson, and P. Vitousek, Principles of Terrestrial Ecosystem Ecology. 2nd ed. 2011, New York: Springer Science \& Business Media.

117. Duveiller, G., J. Hooker, and A. Cescatti, The mark of vegetation change on Earth's surface energy balance. Nature Communications, 2018. 9(1): p. 679.

118. Wan, Z., P. Wang, and X. Li, Using MODIS Land Surface Temperature and Normalized Difference Vegetation Index products for monitoring drought in the southern Great Plains, USA. International Journal of Remote Sensing, 2004. 25(1): p. 61-72.

119. G D Farquhar, a. and T.D. Sharkey, Stomatal Conductance and Photosynthesis. Annual Review of Plant Physiology, 1982. 33(1): p. 317-345.

120. Abdi, A.M., Land cover and land use classification performance of machine learning algorithms in a boreal landscape using Sentinel-2 data. GIScience \& Remote Sensing, 2020. 57(1): p. 1-20.

121. Kussul, N., M. Lavreniuk, S. Skakun, and A. Shelestov, Deep Learning Classification of Land Cover and Crop Types Using Remote Sensing Data. IEEE Geoscience and Remote Sensing Letters, 2017. 14(5): p. 778-782.

122. Xiong, J., P.S. Thenkabail, J.C. Tilton, M.K. Gumma, P. Teluguntla, A. Oliphant, . . N. Gorelick, Nominal 30-m Cropland Extent Map of Continental Africa by Integrating Pixel-Based and Object-Based Algorithms Using Sentinel-2 and Landsat-8 Data on Google Earth Engine. Remote Sensing, 2017. 9(10): p. 1065.

123. Forkuor, G., K. Dimobe, I. Serme, and J.E. Tondoh, Landsat-8 vs. Sentinel-2: examining the added value of sentinel-2's red-edge bands to land-use and land-cover mapping in Burkina Faso. GIScience \& Remote Sensing, 2018. 55(3): p. 331-354.

124. Friedl, M.A., D. Sulla-Menashe, B. Tan, A. Schneider, N. Ramankutty, A. Sibley, and X. Huang, MODIS Collection 5 global land cover: Algorithm refinements and characterization of new datasets. Remote Sensing of Environment, 2010. 114(1): p. 168-182.

125. Mu, Q., M. Zhao, and S. Running, Remote Sensing and Modeling of Global Evapotranspiration, in Multiscale Hydrologic Remote Sensing. 2011, CRC Press. p. 443-480.

126. Dorninger, C., D.J. Abson, J. Fischer, and H. von Wehrden, Assessing sustainable biophysical human-nature connectedness at regional scales. Environmental Research Letters, 2017. 12(5): p. 055001.

127. Johansson, E.L. and A.M. Abdi, Mapping and quantifying perceptions of environmental change in Kilombero Valley, Tanzania. Ambio, 2020. 49(2): p. 557-568.

128. Bradford, G.E., Contributions of animal agriculture to meeting global human food demand. Livestock Production Science, 1999. 59(2-3): p. 95-112.

129. Eltahir, I.E., A.M. Mohamed, O.A. El Khidir, and M. Atta, Feedlot performance and carcass characteristics of Sudan dromedary camels (Camelus dromedarius) fed on molasses and sorghum grain based diets. Journal of Camelid Science, 2011. 4: p. 70-78.

130. Hutjens, M.F. Dairy Efficiency and Dry Matter Intake. in Proceedings of the 7th Western Dairy Management Conference. 2005. Reno, Nevada. .

131. Karim, S.A., A. Santra, and D.L. Verma, Growth, feed conversion efficiency and carcass characteristics of Malpura and Malpura $\times$ Awassi crossbred lambs in a hot semi arid environment. Asian-Australasian Journal of Animal Sciences, 2002. 15(3): p. 377-381.

132. Wirsenius, S., Human use of land and organic materials: modeling the turnover of biomass in the global food system, in Department of Physical Resource Theory. 2000, Chalmers University of Technology: Göteborg, Sweden.

133. IIASA/FAO, Global Agro-ecological Zones (GAEZ v3.0). 2012: IIASA, Laxenburg, Austria and FAO, Rome, Italy. .

134. Pradhan, P., M. K. B. Lüdeke, D. E. Reusser, and J. P. Kropp, Embodied crop calories in animal products. Environmental Research Letters, 2013. 8(4): p. 044044.

135. Goudriaan, J., J.J.R. Groot, and P.W.J. Uithol, Productivity of Agro-ecosystems, in Terrestrial Global Productivity, J. Roy, B. Saugier, and H.A. Mooney, Editors. 2001, Academic Press: San Diego. p. 301-313.

136. Houerou, H.N.L. and C.H. Hoste, Rangeland Production and Annual Rainfall Relations in the Mediterranean Basin and in the African Sahelo-Sudanian Zone. Journal of Range Management, 1977. 30(3): p. 181-189.

137. Jahnke, H.E., Livestock production systems and livestock development in tropical Africa. Vol. 35. 1982, Kiel, Germany: Kieler Wissenschaftsverlag Vauk Kiel.

138. FAOSTAT, FAO Statistical Databases. 2014, Food and Agriculture Organization of the United Nations: Rome, Italy. 


\section{Appendix}

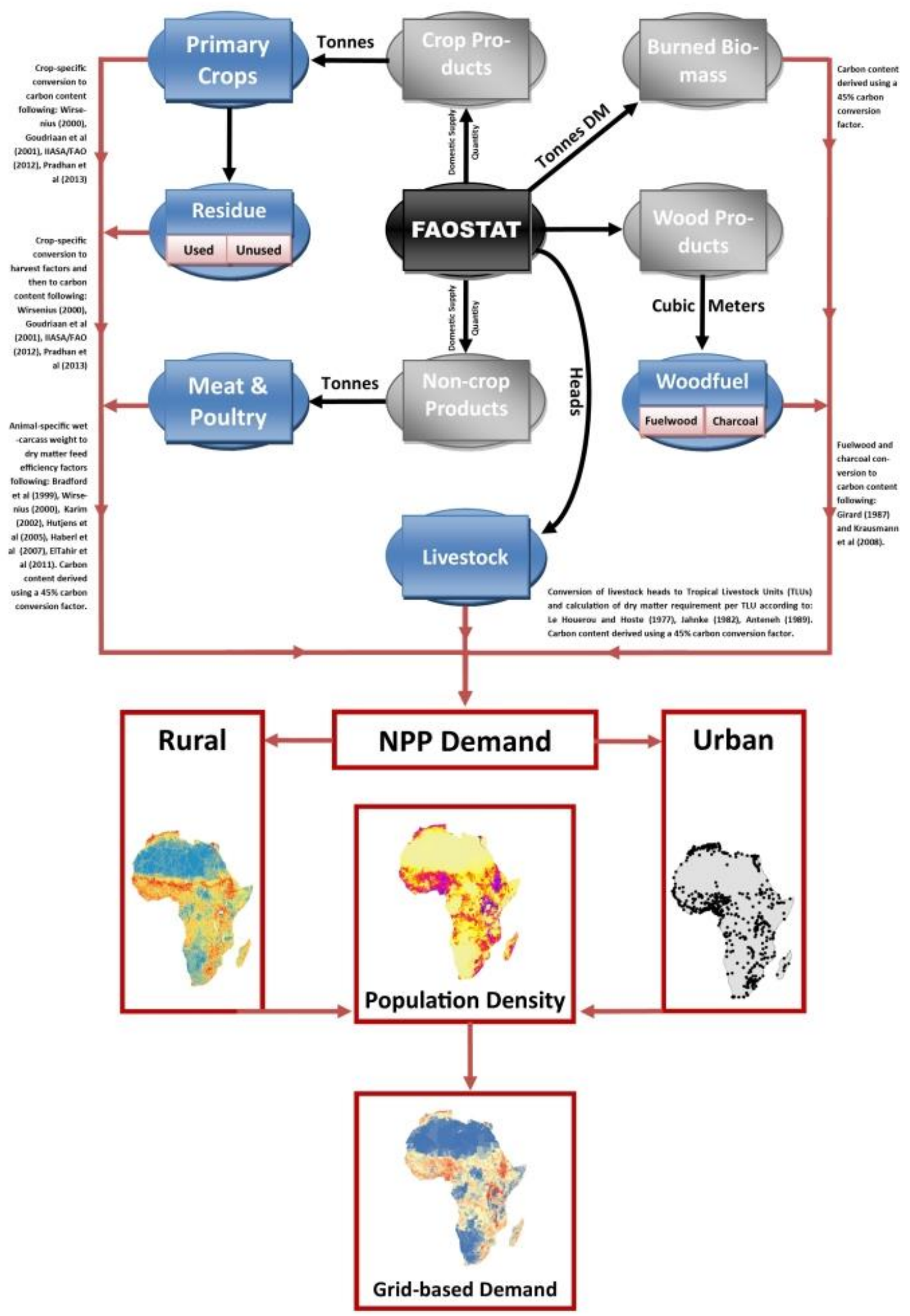

Appendix Figure 1. A visual representation of the framework for estimating demand for NPP. 


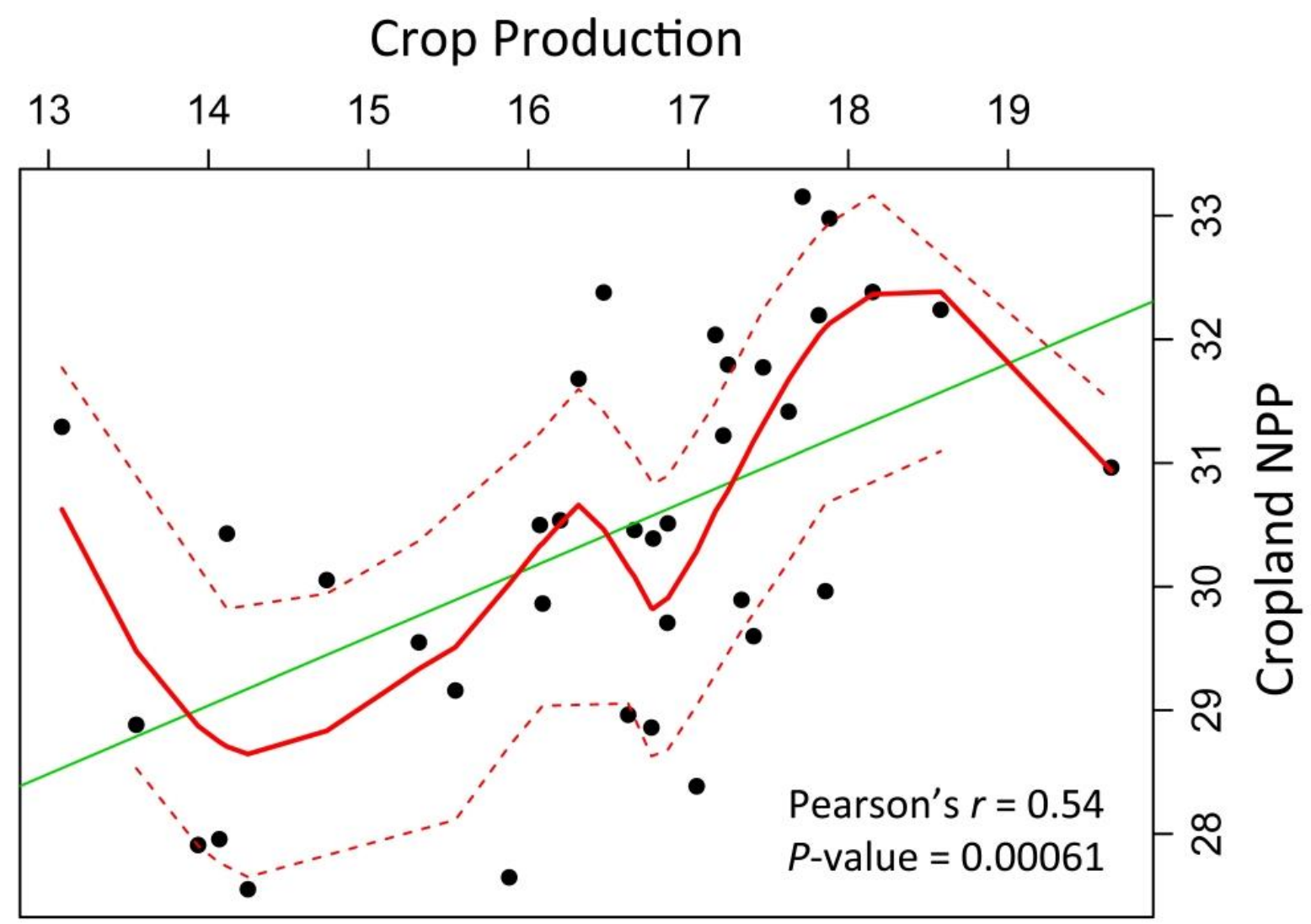

Appendix Figure 2. Correlation between log-transformed dry cropland NPP and FAOSTAT annual crop production for 2000 - 2013. Each data point represents a country listed in Appendix Table 2 and the crop data is an aggregate of the 27 crop types listed in Appendix Table 1. 
Appendix Table 1. Annual dry cropland NPP and FAOSTAT crop production for $2000-2013$ ordered by descending cropland area. Annual NPP was extracted from croplands within arid, semi-arid and dry subhumid zones.

\begin{tabular}{|c|c|c|c|}
\hline Country & $\begin{array}{c}\text { Dry Cropland NPP, } \\
(T g C)\end{array}$ & $\begin{array}{c}\text { Crop Production, } \\
(M t)\end{array}$ & $\begin{array}{c}\text { Dry Cropland area, } \\
\left(\mathrm{km}^{2}\right)\end{array}$ \\
\hline Congo, DRC & 250 & 49 & 305,755 \\
\hline Tanzania & 210 & 58 & 288,980 \\
\hline Sudan & 44 & 45 & 286,990 \\
\hline Nigeria & 28 & 340 & 190,815 \\
\hline Ethiopia & 116 & 76 & 185,481 \\
\hline Zambia & 115 & 14 & 161,100 \\
\hline South Africa & 100 & 117 & 158,365 \\
\hline Mali & 18 & 21 & 146,057 \\
\hline Niger & 8 & 21 & 128,857 \\
\hline Chad & 18 & 11 & 124,077 \\
\hline Mozambique & 82 & 29 & 115,060 \\
\hline Burkina Faso & 16 & 19 & 111,952 \\
\hline Zimbabwe & 57 & 12 & 111,441 \\
\hline Botswana & 39 & 0 & 105,597 \\
\hline Angola & 64 & 31 & 90,359 \\
\hline Uganda & 96 & 55 & 87,863 \\
\hline Kenya & 63 & 39 & 85,870 \\
\hline Malawi & 36 & 30 & 57,776 \\
\hline Somalia & 11 & 3 & 56,633 \\
\hline Senegal & 9 & 10 & 42,616 \\
\hline Namibia & 16 & 1 & 39,378 \\
\hline Cameroon & 7 & 36 & 37,942 \\
\hline Ghana & 10 & 57 & 32,735 \\
\hline Ivory Coast & 10 & 34 & 21,263 \\
\hline Burundi & 18 & 10 & 19,580 \\
\hline Rwanda & 17 & 17 & 17,312 \\
\hline Eritrea & 1 & 1 & 16,559 \\
\hline Guinea & 4 & 17 & 16,473 \\
\hline Central African Republic & 7 & 4 & 14,818 \\
\hline Benin & 3 & 19 & 14,685 \\
\hline Lesotho & 3 & 1 & 7,037 \\
\hline Gambia & 1 & 1 & 5,385 \\
\hline Togo & 1 & 8 & 5,031 \\
\hline Swaziland & 5 & 6 & 4,727 \\
\hline Guinea Bissau & 1 & 2 & 4,506 \\
\hline
\end{tabular}


Appendix Table 2. Conversion rates of products derived from food-producing animals.

\begin{tabular}{l|c|c} 
Type & $\begin{array}{c}\text { Dry Matter } \\
\text { Intake } \\
(\mathbf{K g})\end{array}$ & Reference \\
\hline Beef & 6.5 & Bradford [128] \\
Camel & 12 & Eltahir, Mohamed \\
Eggs & 4 & [129] \\
Milk, whole & 1.5 & Haberl, Erb [103] \\
Mutton/Goat & 6.3 & Karim, Santra [131] \\
Pigmeat & 8.5 & Wirsenius [132] \\
Poultry & 5.5 & $"$ \\
\hline
\end{tabular}


Appendix Table 3. Dry matter and carbon content of the 27 types of crops selected for inclusion into the consumption module.

\begin{tabular}{|c|c|c|c|}
\hline Crop & $\begin{array}{c}\text { Dry Matter } \\
\text { Content } \\
(\%)\end{array}$ & $\begin{array}{c}\text { Carbon } \\
\text { Content } \\
(\%)\end{array}$ & Reference \\
\hline Bananas & 35 & 45 & $\begin{array}{c}\text { IIASA/FAO [133] } \\
\text { Pradhan, K. B. Lüdeke }\end{array}$ \\
\hline Barley & 88 & 47 & {$[134]$} \\
\hline Beans, dry & 90 & 47 & “ \\
\hline Cassava & 38 & 44 & “ \\
\hline Cereals, other & 85 & 47 & “ \\
\hline Dates & 15 & 45 & “ \\
\hline Fruits & 15 & 45 & $\begin{array}{l}\text { Goudriaan, Groot [135] } \\
\text { Pradhan, K. B. Lüdeke }\end{array}$ \\
\hline Grapes & 15 & 45 & {$[134]$} \\
\hline Groundnuts & 95 & 60 & IIASA/FAO [133] \\
\hline Maize & 85 & 49 & Goudriaan, Groot [135] \\
\hline Millet & 88 & 48 & “ \\
\hline Onions, dry & 15 & 45 & $\begin{array}{c}\text { Pradhan, K. B. Lüdeke } \\
\text { [134] }\end{array}$ \\
\hline Oranges & 15 & 45 & “ \\
\hline Plantains & 35 & 45 & “ \\
\hline Potatoes & 25 & 44 & Goudriaan, Groot [135] \\
\hline Pulses & 90 & 47 & “ \\
\hline Rice & 88 & 48 & “ \\
\hline Roots/tubers & 30 & 44 & $\begin{array}{c}\text { Pradhan, K. B. Lüdeke } \\
\text { [134] }\end{array}$ \\
\hline Sorghum & 88 & 48 & Goudriaan, Groot [135] \\
\hline Soybeans & 92 & 52 & “ \\
\hline Sugar beet & 21 & 44 & “ \\
\hline Sugar cane & 27 & 48 & “ \\
\hline Sweet potatoes & 30 & 44 & $\begin{array}{l}\text { IIASA/FAO [133] } \\
\text { Pradhan K B Lijdeke }\end{array}$ \\
\hline Tomatoes & 15 & 45 & [134] \\
\hline Vegetables & 13 & 46 & Goudriaan, Groot [135] \\
\hline Wheat & 87 & 47 & IIASA/FAO [133] \\
\hline Yams & 35 & 44 & $\begin{array}{c}\text { Pradhan, K. B. Lüdeke } \\
\text { [134] }\end{array}$ \\
\hline
\end{tabular}


Appendix Table 4. Conversion factors derived from Houerou and Hoste [136], Jahnke [137], FAOSTAT [138]. For each livestock type to its equivalent tropical livestock unit and the annual amount of dry matter feed each type requires for maintenance.

\begin{tabular}{c|c|c}
$\begin{array}{c}\text { Livestock } \\
\text { Type }\end{array}$ & $\begin{array}{c}\text { Tropical Livestock } \\
\text { Unit Equivalent }\end{array}$ & $\begin{array}{c}\text { Annual Dry Matter } \\
\text { Requirement } \\
(\mathbf{K g})\end{array}$ \\
\hline Camels & 1.00 & 2372 \\
Cattle & 0.70 & 1660 \\
Chickens & 0.01 & 23.72 \\
Goats & 0.10 & 237 \\
Pigs & 0.20 & 474 \\
Sheep & 0.10 & 237 \\
\hline
\end{tabular}


Appendix Table 5. Residue factors for selected crops derived using data from Haberl, Erb [103], Wirsenius [132]. Residue factors are the proportion of total crop phytomass that does not contribute to the crop yield. The inverse of the residue factor is the harvest index.

\begin{tabular}{l|c} 
Crop & Residue Factor \\
\hline Bananas & 0.45 \\
Barley & 0.65 \\
Cassava & 0.80 \\
Cereals, other & 0.60 \\
Dates & 0.85 \\
Fruits & 0.85 \\
Grapes & 0.85 \\
Groundnuts & 0.60 \\
Maize & 0.78 \\
Millet & 0.80 \\
Oranges & 0.85 \\
Plantains & 0.45 \\
Potatoes & 0.50 \\
Pulses & 0.40 \\
Rice & 0.60 \\
Roots and tubers & 0.50 \\
Sorghum & 0.78 \\
Soybeans & 0.60 \\
Sugar beet & 0.70 \\
Sugar cane & 0.40 \\
Sweet potatoes & 0.50 \\
Wheat & 0.70 \\
Yams & 0.50 \\
\hline
\end{tabular}

